\title{
POLSCY OJCOWIE SOBORU WATYKAŃSKIEGO II. WSTEP DO BADAŃ NAD EPISKOPATEM KOŚCIOLA KATOLICKIEGO W PRL W LATACH SZEŚĆDZIESIĄTYCH XX WIEKU
}

\section{Analiza prozopograficzna jako metoda badań nad episkopatem Kościoła katolickiego}

Badania zamkniętych grup korporacyjnych lub społecznych często korzystają z metody prozopograficznej zwanej metodą ,biografii zbiorowej”. Jest ona szczególnie przydatna w analizach stanu duchownego, przy czym na pierwszy plan wysuwają się studia nad duchowieństwem parafialnym, członkami kapituł kolegiackich i katedralnych oraz episkopatem ${ }^{1}$.

W przypadku dziejów najnowszych badania odnoszące się do episkopatu dotyczyły głównie pierwszej połowy XX wieku. Dla przykładu opracowanie materiałów ks. Józefa Umińskiego pozwoliło na zaprezentowanie oryginalnej, choć dyskusyjnej gradacji, która polegała

\footnotetext{
${ }^{1}$ Wśród monografii, które ukazały się w ostatnich kilkunastu latach wymienić należy: S. J u j e c z k a, Duchowni średniowiecznej Legnicy. Studium prozopograficzne nad klerem diecezjalnym, Legnica 2006; T. N o w i c k i, Plebani archidiakonatu pomorskiego w XVIII wieku. Studium prozopograficzne, Lublin 2008; M. Ró ż án s ki, Duchowieństwo parafialne archidiakonatu uniejowskiego $w$ XVIII wieku. Studium prozopograficzne, Łódź 2010; J. S z c z e p a n i a k, Duchowieństwo diecezji krakowskiej w XVIII wieku. Studium prozopograficzne, Kraków 2010; P. D e m b i ń s k i, Poznańska kapituła katedralna schyłku wieków średnich. Studium prozopograficzne 1428-1500, Poznań 2012; R. P r e j s, Administracja diecezjalna w Królestwie Polskim w latach 1864-1918. Studium prozopograficzne, Lublin 2012; D. W e r e d a, Biskupi unickiej metropolii kijowskiej w XVIII wieku, Siedlce-Lublin 2013; R. K r a j n i a k, Duchowieństwo kapituł katedralnej w Chetmży do 1466 roku. Studium prozopograficzne, Toruń 2013; T. Now a k, Duchowieństwo ziemi wieluńskiej $w$ drugiej połowie XV i początku XVI wieku. Studium prozopograficzne, Wieluń 2016.
}

„Nasza Przeszłość” t. 132: 2019, s. 269-315. 
na wyodrębnieniu czterech grup biskupów obrządku łacińskiego: 1) biskupi bardzo dobrzy, czyli znakomici; 2) biskupi dobrzy; 3) biskupi przeciętni; 4) biskupi niedostateczni albo zerowi. Najbardziej problematyczny wydawał się jednak nie sam podział, ale przypisanie do każdej z kategorii konkretnych postaci ${ }^{2}$.

Natomiast autor syntetycznej monografii poświęconej episkopatowi katolickiemu w dwudziestoleciu międzywojennym - ks. Stanisław Wilk SDB - zamieścił ogólną analizę biograficzno-socjologiczną hierarchów zawierającą: 1) przynależność narodowościową; 2) status społeczny; 3) poziom wykształcenia; 4) sektor pracy zawodowej przed nominacją; 5) wiek nominatów; 6) długość sprawowania posługi duszpasterskiej od nominacji do końca życia ${ }^{3}$.

W miejscu tym warto przytoczyć podział polskich hierarchów, jaki zaproponował sam kardynał Stefan Wyszyński na kartach Pro memoria z 1960 r. Prymas Polski dostrzegał głębokie zróżnicowanie wśród dostojników kościelnych, a wiarygodność jego oceny opiera się na wieloletniej, bezpośredniej obserwacji środowiska, któremu osobiście przewodził. Przewodniczący Konferencji Episkopatu Polski wyodrębnił cztery grupy hierarchów. Pierwsza z nich to „biskupi proboszczowie”, druga - najniżej oceniana - „,biskupi szlagoni”, trzecia - „biskupi profesorowie”, czwarta - „biskupi milczący”. Pozytywnym zjawiskiem była dominacja „biskupów profesorów”, którzy pracowali systematycznie, rzetelnie i wytrwale, mocno wspierając kardynała i dźwigając ciężar pracy w komisjach episkopatu ${ }^{4}$.

Niniejszy artykuł nawiązuje do studiów prozopograficznych i ma na celu ukazanie przedstawicieli episkopatu jako zbiorowości ojców Soboru Watykańskiego II. Obrazuje je kilka danych statystycznych. Arcybiskupi i biskupi stanowili bowiem aż 95,5\% polskich ojców soborowych $^{5}$, czyli absolutną większość. Jednocześnie tylko w IV sesji

\footnotetext{
${ }^{2}$ J. U m i ń s k i, Episkopat Polski z pierwszej połowy XX wieku, Toruń 2016, do druku przygotowali, wstępem i przypisami opatrzyli S. Grochowina, J. Sziling, Toruń 2016, s. 3-49.

3 S. W ilk SDB, Episkopat Kościoła katolickiego w Polsce w latach 1918-1939, Warszawa 1992, s. 43-52.

4 Archiwum Archidiecezjalne w Gnieźnie, S. W y s z y ń s ki, Pro memoria, wpis z dnia 30 sierpnia $1960 \mathrm{r}$.

${ }^{5}$ Kategorię polskich ojców soborowych tworzyli: 1) biskupi ordynariusze; 2) biskupi sufragani i rezydujący w Rzymie; 3) wyżsi przełożeni zakonni.
} 
soborowej uczestniczyło aż 46 arcybiskupów i biskupów spośród 63 członków ówczesnego episkopatu ${ }^{6}$. Grupa ta stanowiła aż $73 \%$ członków Konferencji Episkopatu Polski. Natomiast udział wyższych przełożonych zakonnych - nieposiadających sakry biskupiej - miał charakter marginalny, wyłącznie symboliczny $(4,5 \%)$.

Analizując obecność polskich hierarchów w obradach Soboru Watykańskiego II, konieczne jest zastosowanie zarówno ujęcia panoramicznego (szerokiego) - obejmującego tak zwany portret zbiorowy biskupów i wyższych przełożonych zakonnych, oraz ujęcia zindywidualizowanego (wąskiego) - pozwalającego na spojrzenie jednostkowe, zawężone do jednej postaci. Zobiektywizowanie takiej analizy możliwe jest dzięki przyjęciu kryteriów oceny opartych na wspólnych cechach całej grupy. To z kolei może posłużyć jako punkt wyjściowy do zaproponowania klasyfikacji i typologii polskiego episkopatu w okresie PRL?

W przypadku uczestników Soboru Watykańskiego II pochodzących z Polski - arcybiskupów i biskupów oraz wyższych przełożonych zakonnych - zaproponowano cztery kryteria służące opisowi tej zbiorowości:

1) wykształcenie i formacja intelektualna;

2) doświadczenie pasterskie - pokolenie sakry biskupiej (urzędu wyższego przełożonego zakonnego);

3) udział w obradach soborowych;

4) aktywność w obradach soborowych.

${ }^{6}$ M. B i ał k o w s k i, Protokoły konferencji polskich ojców soborowych. Zbiór dokumentów 1962-1965, Lublin 2019, s. 160-161.

7 Portret zbiorowy polskiego episkopatu po drugiej wojnie światowej znalazł się w przyczynku Jana Ż a ry na, Biskupi polscy doby PRL jako przedstawiciele polskich elit, [w:] Biskupi w rzeczywistości politycznej Polski pod rządami komunistów, red. R. Łatka, Warszawa 2019 [w przygotowaniu do druku]. Ostatnio obszerne ujęcie historyczno-politologiczne dla dwóch ostatnich dekad PRL zaprezentował Rafał Łatka, w publikacji Episkopat Polski wobec stosunków państwo-Kościół $i$ rzeczywistości społeczno-politycznej PRL 1970-1989, Warszawa 2019. Historyk związany z Instytutem Pamięci Narodowej dostrzega różnice w postawie poszczególnych biskupów wobec władz i systemu politycznego oraz kilka typów relacji z przedstawicielami reżimu. 


\section{Wykształcenie i formacja intelektualna}

Pierwsze proponowane kryterium odnosi się do szczególnej formy przygotowania merytorycznego w obradach soborowych - kompetencji intelektualnych nabytych w procesie kształcenia. A co za tym idzie, interesować nas tu będą studia wyższe podejmowane w konkretnym ośrodku uniwersyteckim oraz związana $\mathrm{z}$ nimi formacja intelektualna. Przyczynia się ona do pogłębienia sprawności umysłowej oraz do kształcenia racjonalnej postawy względem prawdy naukowej. Jest też naturalnym następstwem wyboru uczelni, gdyż towarzyszą jej uwarunkowania kulturowo-społeczne panujące w miejscu kształcenia.

Wyniesione wraz z dyplomem macierzystej uczelni przywiązanie do kierunków i szkół teologicznych często uobecniało się w pracach soborowych. Sobór Watykański II był bowiem - jak każde tego typu zgromadzenie w historii Kościoła - areopagiem, na którym nie tylko spotykały się, ale często ścierały się współczesne koncepcje, nurty i poglądy filozoficzno-teologiczne. Udział w debatach soborowych wymagał doskonałej znajomości doktryny katolickiej oraz biegłości wypowiedzi. Duże znaczenie miały praktyczne umiejętności lingwistyczne zdobyte podczas studiów zagranicznych. Oprócz płynnej znajomości łaciny, która była językiem obrad, przydatna była również znajomość języków nowożytnych - szczególnie włoskiego, francuskiego, niemieckiego, hiszpańskiego i angielskiego.

Zebrane $\mathrm{w}$ tabeli numer 1 dane - na podstawie biogramów oraz prac monograficznych poświęconych poszczególnym hierarchom pozwalają formułować następujące wnioski. Spośród 19 biskupów ordynariuszy i rządców diecezji 12 posiadało doktorat (63,2\%), 1 - profesurę tytularną (odpowiednik docenta) $)^{8}(5,3 \%), 2$ - stopień doktora habilitowanego $(10,5 \%)$ i 4 - tytuł profesora zwyczajnego $(21 \%)$. Konieczna jest w tym miejscu uwaga, że zdecydowana większość hierarchów wchodzących w skład tej grupy prowadziła zajęcia dydaktyczne w wyższych seminariach duchownych oraz na uczelniach kościelnych. Spora część mogła wylegitymować się znaczącym dorobkiem naukowym. Szeroki wachlarz dyscyplin naukowych obejmował

\footnotetext{
${ }^{8}$ System szkolnictwa wyższego i jego reformy w latach 1918-1939 omawia szczegółowo publikacja: M. Pr z e n i o s ło, Stopnie, tytuły i stanowiska naukowe w II Rzeczypospolitej, „Res Historica. Czasopismo Instytutu Historii UMCS” 2012, t. 33, s. $151-170$.
} 
przede wszystkim filozofię, teologię, historię Kościoła i prawo kanoniczne. Badania naukowe - bez wątpienia - stanowiły ważną kartę w życiorysie kardynała Stefana Wyszyńskiego (katolicka nauka społeczna), arcybiskupa Karola Wojtyły (etyka, filozofia chrześcijańska), biskupów: Stefana Bareły (teologia moralna), Czesława Falkowskiego (historia Kościoła), Zdzisława Golińskiego (teologia moralna), Piotra Kałwy (prawo kanoniczne), Michała Klepacza (filozofia chrześcijańska), Kazimierza Józefa Kowalskiego (mariologia, misjologia), Edmunda Nowickiego (prawo kanoniczne), Antoniego Pawłowskiego (mariologia, ekumenizm) oraz Wilhelma Pluty (teologia pastoralna $)^{9}$.

Natomiast wśród biskupów sufraganów i rezydujących w Rzymie (łącznie 44 hierarchów) - uczestników obrad Soboru Watykańskiego II - zauważalne jest zróżnicowanie w poziomie wykształcenia. Badanie objęło 42 dostojników. Poza zestawieniem znaleźli się dwaj biskupi, którzy nie ukończyli uczelni o statusie uniwersyteckim. Byli to: sufragan poznański biskup Tadeusz Etter oraz sufragan chełmiński biskup Bernard Czapliński. W pewnym stopniu niedobór wiedzy akademickiej zastępował im bardzo wysoki poziom studiów filozoficznoteologicznych w seminariach duchownych. Biskup Tadeusz Etter był absolwentem Arcybiskupiego Seminarium Duchownego w Poznaniu $^{10}$, zaś biskup Bernard Czapliński Wyższego Seminarium Duchownego w Pelplinie ${ }^{11}$.

Tytułem magistra lub licencjata legitymowało się 15 biskupów z badanej grupy (35,7\%). Doktoratem mogło natomiast pochwalić się 26 biskupów sufraganów oraz rezydujących w Rzymie (61,9\%). Stopień doktora habilitowanego uzyskał tylko jeden z dostojników - sufragan sandomierski biskup Walenty Wójcik, który był wykładowcą prawa kanonicznego (2,4\%). Natomiast spośród przybyłych na Sobór trzech wyższych przełożonych zakonnych - jeden posiadał tytuł magistra $(33,3 \%)$, a dwóch doktora $(66,7 \%)$.

9 Interesujące porównanie przynosi szczegółowa analiza wykształcenia polskiego episkopatu w dwudziestoleciu międzywojennym: S. W i 1 k SDB, Episkopat Kościoła katolickiego w Polsce w latach 1918-1939, s. 44-47.

${ }^{10}$ P. N i t e c k i, Biskupi Kościoła w Polsce. Stownik biograficzny, Warszawa 1992, s. 56.

11 T. B o r c z, Biskup Bernard Czapliński w stużbie Kościoła chetmińskiego, „Studia Pelplińskie" 1980, nr 11, s. 23-30. 
Analizując wykształcenie wszystkich polskich ojców soborowych (66 hierarchów), stwierdzić należy, że 2 hierarchów (3\%) formalnie nie uzyskało stopnia bądź tytułu naukowego; $16(24,3 \%)$ - posiadało tytuł magistra bądź licencjata; $41(62,1 \%)$ - posiadało stopień doktora lub profesora tytularnego; 7 (10,6\%) - posiadało co najmniej stopień doktora habilitowanego, profesora nadzwyczajnego lub profesora zwyczajnego.

Wiążąc wykształcenie polskich ojców soborowych z aktywnością (wystąpieniami w auli soborowej), warto podkreślić, że jedynym hierarchą, który wygłaszał przemówienie podczas Kongregacji Generalnej i nie posiadał co najmniej doktoratu, był sufragan krakowski biskup Jan Pietraszko ${ }^{12}$.

Większość polskich ojców soborowych posiadała wykształcenie z zakresu dyscyplin typowo kościelnych. Prawie wszyscy mogli pochwalić się studiami filozoficznymi, teologicznymi, historycznymi bądź prawniczymi (z zakresu prawa kanonicznego). Wielu ukończyło dwa kierunki.

Wśród nielicznych, którzy studiowali kierunki świeckie, wskazać można między innymi sufragana łomżyńskiego biskupa Aleksandra Mościckiego. Hierarcha w 1928 roku uzyskał dyplom magisterski z ekonomii społecznej i nauk politycznych na Wydziale PrawnoEkonomicznym Uniwersytetu Poznańskiego ${ }^{13}$. Sufragan warszawski biskup Bronisław Dąbrowski FDP w 1943 roku ukończył konspiracyjne studia na Wydziale Pedagogicznym Uniwersytetu Warszawskiego ${ }^{14}$. Z kolei sufragan chełmiński biskup Zygfryd Kowalski w 1951 roku w Uniwersytecie Mikołaja Kopernika w Toruniu obronił doktorat z zakresu pedagogiki i dydaktyki, uzyskując stopień doktora nauk humanistycznych ${ }^{15}$.

\footnotetext{
${ }^{12}$ L. G r y g i e 1, Prorok ze św. Anny. Biskup Jan Pietraszko, Kraków 2017, s. 102-108.

${ }^{13}$ T. K r a h e 1, Biskup Aleksander Mościcki, ,W Służbie Miłosierdzia” 1/2010.

14 K. R. P roko p, Biskupi Kościoła katolickiego w III Rzeczpospolitej. Leksykon biograficzny, Kraków 1998, s. 27.

${ }^{15}$ W. K a s y n a, Bp Zygfryd Ignacy Kowalski (1910-1995), [w:] Księga Jubileuszowa 350 lat Wyższego Seminarium Duchownego w Pelplinie (1651-2001), red. A. N a d o 1 n y, Pelplin 2001, s. 449-459.
} 
Tab. 1. Polscy ojcowie soborowi według stopnia lub tytułu naukowego (stan na dzień 8 grudnia 1965 r.)*

A. Biskupi ordynariusze

\begin{tabular}{|c|c|c|c|c|c|c|}
\hline Imię i nazwisko biskupa & 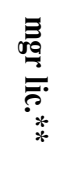 & $\because$ & 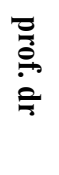 & 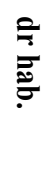 & 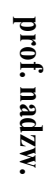 & 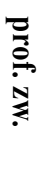 \\
\hline kardynał Stefan Wyszyński & & + & & & & \\
\hline arcybiskup Antoni Baraniak & & + & & & & \\
\hline arcybiskup Bolesław Kominek & & + & & & & \\
\hline arcybiskup Karol Wojtyła & & & & + & & \\
\hline biskup Jerzy Ablewicz & & + & & & & \\
\hline biskup Franciszek Barda & & + & & & & \\
\hline biskup Stefan Bareła & & + & & & & \\
\hline biskup Czesław Falkowski & & & & & & + \\
\hline biskup Zdzisław Goliński & & & & + & & \\
\hline biskup Jan Jaroszewicz & & + & & & & \\
\hline biskup Franciszek Jop & & + & & & & \\
\hline biskup Piotr Kałwa & & & & & & + \\
\hline biskup Michał Klepacz & & & + & & & \\
\hline biskup Kazimierz J. Kowalski & & & & & & + \\
\hline biskup Edmund Nowicki & & + & & & & \\
\hline biskup Antoni Pawłowski & & & & & & + \\
\hline biskup Wilhelm Pluta & & + & & & & \\
\hline biskup Bogdan Sikorski & & + & & & & \\
\hline biskup Tomasz Wilczyński & & + & & & & \\
\hline
\end{tabular}


B. Biskupi sufragani i rezydujący w Rzymie

\begin{tabular}{|c|c|c|c|c|c|c|}
\hline Imię i nazwisko biskupa & 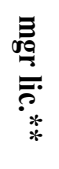 & $\fallingdotseq$ & 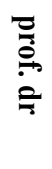 & 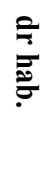 & 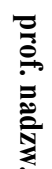 & 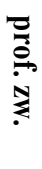 \\
\hline biskup Herbert Bednorz & & + & & & & \\
\hline biskup Bohdan Bejze & & + & & & & \\
\hline biskup Lucjan Bernacki & & + & & & & \\
\hline biskup Juliusz Bieniek & + & & & & & \\
\hline biskup Zygmunt Choromański & & + & & & & \\
\hline biskup Jan Czerniak & + & & & & & \\
\hline biskup Bronisław Dąbrowski & + & & & & & \\
\hline biskup Józef Drzazga & & + & & & & \\
\hline biskup Piotr Dudziec & + & & & & & \\
\hline biskup Jan Fondaliński & & + & & & & \\
\hline biskup Julian Groblicki & & + & & & & \\
\hline biskup Henryk Grzondziel & & + & & & & \\
\hline biskup Stanisław Jakiel & & + & & & & \\
\hline biskup Franciszek Jedwabski & + & & & & & \\
\hline biskup Ignacy Jeż & + & & & & & \\
\hline biskup Lech Kaczmarek & & + & & & & \\
\hline biskup Zygfryd Kowalski & & + & & & & \\
\hline biskup Jan Kulik & & + & & & & \\
\hline biskup Józef Kurpas & + & & & & & \\
\hline biskup Paweł Latusek & & + & & & & \\
\hline biskup Kazimierz Majdański & & + & & & & \\
\hline biskup Wacław Majewski & + & & & & & \\
\hline biskup Jan Mazur & & + & & & & \\
\hline biskup Jerzy Modzelewski & & + & & & & \\
\hline biskup Aleksander Mościcki & + & & & & & \\
\hline biskup Edward Muszyński & & + & & & & \\
\hline biskup Jan Obłąk & & + & & & & \\
\hline biskup Karol Pękala & & + & & & & \\
\hline biskup Jan Pietraszko & + & & & & & \\
\hline biskup Wacław Skomorucha & + & & & & & \\
\hline
\end{tabular}




\begin{tabular}{|l|c|c|c|c|l|l|}
\hline biskup Henryk Strąkowski & & + & & & & \\
\hline biskup Jerzy Stroba & & + & & & & \\
\hline biskup Tadeusz Szwagrzyk & & + & & & & \\
\hline biskup Bolesław Taborski & + & & & & & \\
\hline biskup Wincenty Urban & & + & & & & \\
\hline biskup Jan Wosiński & & + & & & & \\
\hline biskup Walenty Wójcik & & & & + & & \\
\hline biskup Andrzej Wronka & & + & & & & \\
\hline biskup Wacław Wycisk & + & & & & & \\
\hline biskup Jan Zaręba & + & & & & & \\
\hline biskup Władysław Rubin & & + & & & & \\
\hline arcybiskup Józef Gawlina & + & & & & & \\
\hline
\end{tabular}

C. Wyżsi przełożeni zakonni

\begin{tabular}{|c|c|c|c|c|c|c|}
\hline $\begin{array}{c}\text { Imię i nazwisko } \\
\text { wyższego przełożonego }\end{array}$ & 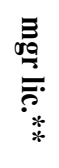 & $\fallingdotseq$ & $\begin{array}{l}\stackrel{5}{0} \\
\stackrel{\leftrightarrow}{7}\end{array}$ & 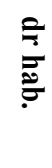 & 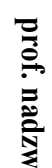 & 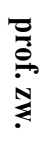 \\
\hline ojciec Augustyn Ciesielski OCist & & + & & & & \\
\hline ojciec Ludwik Nowak OSPPE & + & & & & & \\
\hline ojciec Jerzy Tomziński OSPPE & & + & & & & \\
\hline
\end{tabular}

\begin{tabular}{|c|c|c|c|c|c|c|}
\hline \multirow[t]{2}{*}{ Lącznie $(A+B+C)$} & 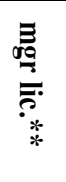 & $\fallingdotseq$ & 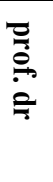 & 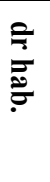 & 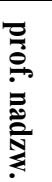 & 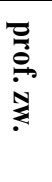 \\
\hline & 16 & 40 & 1 & 3 & - & 4 \\
\hline
\end{tabular}

Źródło: P. Nitecki, Biskupi Kościoła w Polsce. Stownik biograficzny, Warszawa 1992; K.R. Prokop, Biskupi Kościoła katolickiego w III Rzeczpospolitej. Leksykon biograficzny, Kraków 1998 oraz wybrane prace monograficzne poświęcone polskim biskupom.

* Każdemu nazwisku został przypisany ostatni najwyższy stopień lub tytuł naukowy, który został formalnie uzyskany przed zakończeniem obrad Soboru Watykańskiego II.

** W systemie kościelnego szkolnictwa wyższego stopień licencjata, zwany również licencjatem rzymskim, jest częścią rzymskiego systemu stopni naukowych i w hierarchii zajmuje miejsce pomiędzy magisterium a doktoratem. 
Wykres 1. Liczba polskich ojców soborowych według godności oraz stopnia lub tytułu naukowego

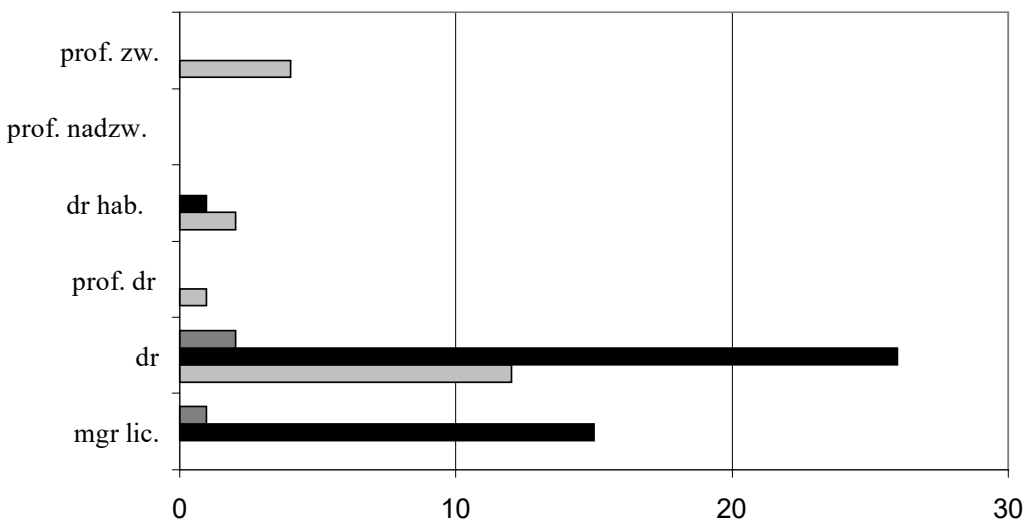

Biskupi ordynariusze

Biskupi sufragani i rezydujący w Rzymie

$\square$ Wyżsi przełożeni zakonni

Wykres 2. Polscy ojcowie soborowi według stopnia lub tytułu naukowego

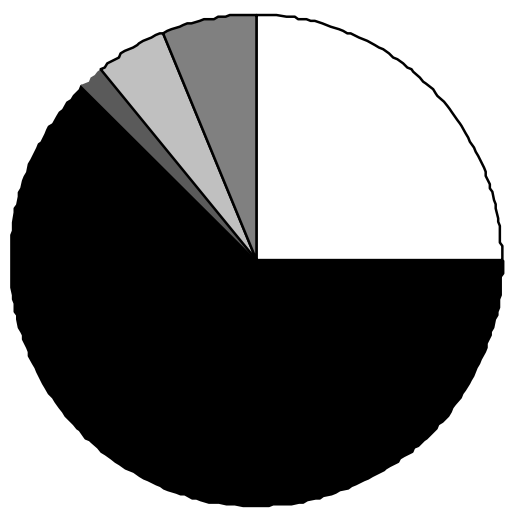

$\square$ mgr lic.

$\square \mathrm{dr}$

a prof. dr

$\square$ dr hab.

$\square$ prof. nadzw.

$\square$ prof. zw. 
Polscy ojcowie soborowi swoje przygotowanie pastoralno-teologiczne do udziału w obradach soborowych zawdzięczali solidnemu wykszta1ceniu zdobywanemu zarówno na uczelniach krajowych, jak i zagranicznych. Z 66 obecnych - w różnym czasie - na Soborze Watykańskim II hierarchów z Polski, aż 34 (51,5\%) odbyło studia zagraniczne, przy czym w kilku przypadkach nie były one zwieńczone uzyskaniem stopnia lub tytułu naukowego. Sytuacje takie wynikały najczęściej z przypadków losowych. Przyszły sufragan warmiński ksiądz Józef Drzazga, jak i ksiądz Jan Zaręba, przyszły sufragan włocławski, przebywali tylko rok na Papieskim Uniwersytecie Gregoriańskim w Rzymie (1938-1939) ${ }^{16}$. Również przyszły sufragan warszawski kleryk Bronisław Dąbrowski FDP tylko przez dwa lata (1937-1939) studiował w Międzynarodowym Instytucie Filozoficznym Orionistów w Tortonie we Włoszech ${ }^{17}$. Studia - w tych przypadkach - przerwał wybuch drugiej wojny światowej.

Jednocześnie dla 18 polskich ojców soborowych studia zagraniczne były drugimi studiami (27,3\% spośród wszystkich polskich hierarchów uczestniczących w Soborze). Natomiast 16 podjęło wyłącznie studia zagraniczne $(24,2 \%$ spośród wszystkich polskich hierarchów uczestniczących w Soborze).

Wśród zagranicznych ośrodków uniwersyteckich pozycja niekwestionowanego lidera przysługuje Rzymowi ${ }^{18}$. W Wiecznym Mieście studiowało aż 17 polskich ojców soborowych (25,8\% spośród wszystkich polskich hierarchów uczestniczących w Soborze). Kolejne miejsce zajmuje Wrocław (Breslau) - 4 ojców soborowych $(6,1 \%)$. Trzecie miejsce ex aequo sześć innych ośrodków: Fryburg Szwajcarski 2 ojców soborowych (3\%), Innsbruck - 2 ojców soborowych $(3 \%)$, Louvain -2 ojców soborowych (3\%), Paryż - 2 ojców soborowych (3\%), Petersburg - 2 ojców soborowych (3\%), Strasburg - 2 ojców soborowych (3\%). Krótkiego komentarza wymagają na pewno studia w Petersburgu. Przypomnijmy zatem, że w latach 1842-1918 jedyną

\footnotetext{
${ }^{16}$ A. K o p i c z k o, Józef Drzazga, [w:] Poczet biskupów warmińskich, red. S. A c h r e m c z y k, Olsztyn 2008, s. 457-458; Z. G m u r c z y k, Kościół włocławski w rzeczywistości PRL-u za czasów biskupa Antoniego Pawłowskiego (1951-1968), Włocławek 2015, s. 154-155.

${ }^{17}$ P. R a i n a, Arcybiskup Bronistaw Dabrowski. Portret, Warszawa 2008, s. 8.

18 Zob. R. S e l e j d a k, Tożsamość $i$ działalność instytucji formacji kapłańskiej $w$ Rzymie, „Collectanea Theologica” 79/1, 2009, s. 51-83.
} 
wyższą uczelnią kościelną na obszarze Rosji była Cesarska Rzymskokatolicka Akademia Duchowna w Petersburgu. Tylko ona posiadała prawo do nadawania stopni i tytułów naukowych w zakresie teologii katolickiej i jej subdyscyplin. W 1918 roku jej pracownicy wraz z jej bogatymi zbiorami bibliotecznymi stanowili podstawę nowo powstałego Katolickiego Uniwersytetu Lubelskiego ${ }^{19}$.

Pojedynczy dostojnicy odbyli studia zagraniczne w Krakowie, Lubljanie, Tortonie, Münster, Lille i Bejrucie (Liban). To ostatnie nietypowe miejsce studiów związane było z wojenną tułaczką przyszłego sufragana gnieźnieńskiego oraz delegata Prymasa Polski do opieki nad emigracją i uchodźstwem polskim biskupa Władysława Rubina. W latach 1943-1946 - jeszcze przed święceniami kapłańskimi - studiował na Uniwersytecie św. Józefa w Bejrucie ${ }^{20}$.

Różnego typu studia w kraju odbyło 49 polskich ojców soborowych, a więc 74,2\% dostojników. Najczęściej wybierano Katolicki Uniwersytet Lubelski - 22 ojców soborowych (33,3\%). Kolejne miejsca zajmowały Uniwersytet Jagielloński w Krakowie - 19 ojców soborowych $(28,8 \%)$, Uniwersytet Warszawski - 7 ojców soborowych $(10,6 \%)$, Uniwersytet Jana Kazimierza we Lwowie - 5 ojców soborowych (7,6\%), Uniwersytet Poznański - 2 ojców soborowych (3\%). Pojedynczy legitymowali się dyplomami: Uniwersytetu Stefana Batorego w Wilnie, Uniwersytetu Mikołaja Kopernika w Toruniu oraz Akademii Teologii Katolickiej w Warszawie.

\footnotetext{
${ }^{19}$ I. W odzi a now s ka, Rzymskokatolicka Akademia Duchowna w Petersburgu, Lublin 2007, s. 285-291.

${ }^{20}$ W. S z e te $\ln$ i c ki, Lwowianin na drogach świata, Wtadysław Kardynat Rubin, Roma 1985, s. 70-73.
} 
Tab. 2. Polscy ojcowie soborowi według miejsca studiowania (z pominięciem ukończonych wyższych seminariów duchownych) i jego przynależności państwowej (stan na dzień 8 grudnia 1965 r.)*

A. Biskupi ordynariusze

\begin{tabular}{|c|c|}
\hline Imię i nazwisko biskupa & $\begin{array}{l}\text { Nazwa uczelni, siedziba, } \\
\text { przynależność państwowa }\end{array}$ \\
\hline kardynał Stefan Wyszyński & Katolicki Uniwersytet Lubelski (Lublin, Polska) \\
\hline arcybiskup Antoni Baraniak & $\begin{array}{l}\text { Pontificia Universitas Gregoriana } \\
\text { (Rzym, Watykan) }\end{array}$ \\
\hline arcybiskup Bolesław Kominek & $\begin{array}{l}\text { Uniwersytet Jagielloński (Kraków, Polska) } \\
\text { L'Institut Catholique de Paris (Paryż, Francja) }\end{array}$ \\
\hline arcybiskup Karol Wojtyła & $\begin{array}{l}\text { Uniwersytet Jagielloński (Kraków) } \\
\text { Pontificium Athenaeum Internationale } \\
\text { Angelicum (Rzym, Watykan) }\end{array}$ \\
\hline biskup Jerzy Ablewicz & Katolicki Uniwersytet Lubelski (Lublin, Polska) \\
\hline biskup Franciszek Barda & $\begin{array}{l}\text { Uniwersytet Jagielloński (Kraków, Polska) } \\
\text { Pontificia Universitas Gregoriana } \\
\text { (Rzym, Watykan) }\end{array}$ \\
\hline biskup Stefan Bareła & $\begin{array}{l}\text { Uniwersytet Jagielloński (Kraków, Polska) } \\
\text { Katolicki Uniwersytet Lubelski (Lublin, Polska) }\end{array}$ \\
\hline biskup Czesław Falkowski & $\begin{array}{l}\text { Римско-Католическая духовная академия } \\
\text { в Петербурге (Petersburg, Zwiazek Sowiecki)* } \\
\text { Leopold-Franzens-Universität Innsbruck } \\
\text { (Innsbruck, Austria) }\end{array}$ \\
\hline biskup Zdzisław Goliński & $\begin{array}{l}\text { Katolicki Uniwersytet Lubelski (Lublin, Polska) } \\
\text { Pontificia Universitas Gregoriana } \\
\text { (Rzym, Watykan) } \\
\text { Pontificium Athenaeum Internationale } \\
\text { Angelicum (Rzym, Watykan) }\end{array}$ \\
\hline biskup Jan Jaroszewicz & $\begin{array}{l}\text { Katolicki Uniwersytet Lubelski (Lublin, Polska) } \\
\text { Université de Fribourg (Fryburg, Szwajcaria) }\end{array}$ \\
\hline biskup Franciszek Jop & $\begin{array}{l}\text { Pontificia Universitas Gregoriana } \\
\text { (Rzym, Watykan) }\end{array}$ \\
\hline
\end{tabular}




\begin{tabular}{|l|l|}
\hline biskup Piotr Kałwa & $\begin{array}{l}\text { Katolicki Uniwersytet Lubelski (Lublin, Polska) } \\
\text { Uniwersytet Jana Kazimierza } \\
\text { (Lwów, Związek Sowiecki) }\end{array}$ \\
\hline biskup Michał Klepacz & $\begin{array}{l}\text { Pимско-Kатолическая духовная академия } \\
\text { в Петербурге (Petersburg, Związek Sowiecki)* } \\
\text { Katolicki Uniwersytet Lubelski (Lublin, Polska) } \\
\text { Uniwersytet Jagielloński (Kraków, Polska) }\end{array}$ \\
\hline biskup Kazimierz J. Kowalski & $\begin{array}{l}\text { Université de Strasburg (Strasburg, Francja) } \\
\text { Université catholique de Louvain } \\
\text { (Louvain, Belgia) } \\
\text { Uniwersytet Jagielloński (Kraków, Polska) } \\
\text { Uniwersytet Poznański (Poznań, Polska) }\end{array}$ \\
\hline biskup Edmund Nowicki & $\begin{array}{l}\text { Pontificia Universitas Gregoriana } \\
\text { (Rzym, Watykan) } \\
\text { Tribunal Rotae Romanae (Rzym, Watykan) }\end{array}$ \\
\hline biskup Antoni Pawłowski & Uniwersytet Warszawski (Warszawa, Polska) \\
\hline biskup Wilhelm Pluta & Uniwersytet Jagielloński (Kraków, Polska) \\
\hline biskup Bogdan Sikorski & $\begin{array}{l}\text { Uniwersytet Jagielloński (Kraków, Polska) } \\
\text { Katolicki Uniwersytet Lubelski (Lublin, Polska) }\end{array}$ \\
\hline biskup Tomasz Wilczyński & $\begin{array}{l}\text { Pontificia Universitas Gregoriana } \\
\text { Rzym, Watykan) }\end{array}$ \\
\hline
\end{tabular}

B. Biskupi sufragani i rezydujący w Rzymie

\begin{tabular}{|l|l|}
\hline \multicolumn{1}{|c|}{ Imię i nazwisko biskupa } & \multicolumn{1}{c|}{$\begin{array}{c}\text { Nazwa uczelni, siedziba, } \\
\text { przynależność państwowa }\end{array}$} \\
\hline biskup Herbert Bednorz & $\begin{array}{l}\text { Uniwersytet Jagielloński (Kraków, Polska) } \\
\text { Université de Paris (Paryż, Francja) }\end{array}$ \\
\hline biskup Bohdan Bejze & Katolicki Uniwersytet Lubelski (Lublin, Polska) \\
\hline biskup Lucjan Bernacki & $\begin{array}{l}\text { Université de Strasburg (Strasburg, Francja) } \\
\text { Pontificia Universitas Gregoriana } \\
\text { (Rzym, Watykan) }\end{array}$ \\
\hline biskup Juliusz Bieniek & $\begin{array}{l}\text { Friedrich-Wilhelms-Universität Breslau } \\
\text { (Wrocław, Polska) } * * *\end{array}$ \\
\hline
\end{tabular}




\begin{tabular}{|l|l|}
\hline biskup Zygmunt Choromański & $\begin{array}{l}\text { Pontificia Universitas Gregoriana } \\
\text { (Rzym, Watykan) }\end{array}$ \\
\hline biskup Jan Czerniak & Uniwersytet Jagielloński (Kraków, Polska) \\
\hline biskup Bronisław Dąbrowski & $\begin{array}{l}\text { Międzynarodowy Instytut Filozoficzny Orio- } \\
\text { nistów (Tortona, Włochy) } \\
\text { Uniwersytet Warszawski (Warszawa, Polska) }\end{array}$ \\
\hline biskup Józef Drzazga & $\begin{array}{l}\text { Pontificia Universitas Gregoriana } \\
\text { (Rzym, Watykan) } \\
\text { Katolicki Uniwersytet Lubelski (Lublin, Polska) }\end{array}$ \\
\hline biskup Piotr Dudziec & $\begin{array}{l}\text { Uniwersytet Jana Kazimierza } \\
\text { (Lwów, Związek Sowiecki) ** }\end{array}$ \\
\hline biskup Jan Fondaliński & $\begin{array}{l}\text { Université catholique de Louvain } \\
\text { (Louvain, Belgia) } \\
\text { Uniwersytet Jana Kazimierza } \\
\text { (Lwów, Związek Sowiecki) } * \\
\text { Katolicki Uniwersytet Lubelski (Lublin, Polska) }\end{array}$ \\
\hline biskup Julian Groblicki & $\begin{array}{l}\text { Uniwersytet Jagielloński (Kraków, Polska) } \\
\text { Papieski Instytut Międzynarodowy Angelicum } \\
\text { (Rzym, Watykan) }\end{array}$ \\
\hline biskup Henryk Grzondziel & $\begin{array}{l}\text { Friedrich-Wilhelms-Universität Breslau } \\
\text { (Wrocław, Polska)*** }\end{array}$ \\
\hline biskup Stanisław Jakiel & Collegium Canisianum (Innsbruck, Austria) \\
\hline biskup Franciszek Jedwabski Józef Kurpas & $\begin{array}{l}\text { Westfälische Wilhelms-Universität Münster } \\
\text { (Münster, Niemcy) }\end{array}$ \\
\hline biskup Ignacy Jeż & Uniwersytet Jagielloński (Kraków, Polska) \\
\hline biskup Lech Kaczmarek & $\begin{array}{l}\text { Pontificia Universitas Gregoriana } \\
\text { (Rzym, Watykan) }\end{array}$ \\
\hline $\begin{array}{l}\text { Uniwersytet Mikołaja Kopernika } \\
\text { (Torun, Polska) }\end{array}$ \\
\hline $\begin{array}{l}\text { Kniwersytet Warszawski (Warszawa, Polska) } \\
\text { (Warszawa, Polska) }\end{array}$ \\
\hline biskicki Uniwersytet Lubelski (Lublin, Polska)
\end{tabular}




\begin{tabular}{|l|l|}
\hline biskup Paweł Latusek & $\begin{array}{l}\text { Uniwersytet Jagielloński (Kraków, Polska) } \\
\text { École des Missionaires du Travail } \\
\text { Lille, Francja) } \\
\text { Katolicki Uniwersytet Lubelski (Lublin, Polska) }\end{array}$ \\
\hline biskup Kazimierz Majdański & Université de Fribourg (Fryburg, Szwajcaria) \\
\hline biskup Wacław Majewski & Uniwersytet Warszawski (Warszawa, Polska) \\
\hline biskup Jan Mazur & Katolicki Uniwersytet Lubelski (Lublin, Polska) \\
\hline biskup Jerzy Modzelewski & Katolicki Uniwersytet Lubelski (Lublin, Polska) \\
\hline biskup Aleksander Mościcki & $\begin{array}{l}\text { Uniwersytet Stefana Batorego } \\
\text { (Wilno, Związek Sowiecki)*** }\end{array}$ \\
\hline Uniwersytet Poznański (Poznań, Polska)
\end{tabular}




\begin{tabular}{|l|l|}
\hline biskup Andrzej Wronka & Uniwersytet Poznański (Poznań, Polska) \\
\hline biskup Wacław Wycisk & $\begin{array}{l}\text { Friedrich-Wilhelms-Universität Breslau } \\
\text { (Wrocław, Polska)*** } \\
\text { Katolicki Uniwersytet Lubelski (Lublin, Polska) }\end{array}$ \\
\hline biskup Jan Zaręba & $\begin{array}{l}\text { Pontificia Universitas Gregoriana } \\
\text { (Rzym, Watykan) } \\
\text { Uniwersytet Jagielloński (Kraków, Polska) }\end{array}$ \\
\hline biskup Władysław Rubin & $\begin{array}{l}\text { Université Saint-Joseph (Bejrut, Liban) } \\
\text { Pontificia Universitas Gregoriana } \\
\text { (Rzym, Watykan) } \\
\text { Tribunal Rotae Romanae (Rzym, Watykan) }\end{array}$ \\
\hline arcybiskup Józef Gawlina & $\begin{array}{l}\text { Friedrich-Wilhelms-Universität Breslau } \\
\text { (Wrocław, Polska)*** } \\
\text { Uniwersytet Warszawski (Warszawa, Polska) }\end{array}$ \\
\hline
\end{tabular}

C. Wyżsi przełożeni zakonni

\begin{tabular}{|l|l|}
\hline $\begin{array}{c}\text { Imię i nazwisko } \\
\text { wyższego przelożonego }\end{array}$ & \multicolumn{1}{c|}{$\begin{array}{c}\text { Nazwa uczelni, siedziba, } \\
\text { przynależność państwowa }\end{array}$} \\
\hline ojciec Augustyn Ciesielski OCist & $\begin{array}{l}\text { Uniwersytet Jagielloński (Kraków, Polska) } \\
\text { Univerza v Ljubljani (Lubljana, Jugosławia) }\end{array}$ \\
\hline ojciec Ludwik Nowak OSPPE & $\begin{array}{l}\text { Pontificium Athenaeum Internationale Ange- } \\
\text { licum (Rzym, Watykan) } \\
\text { Pontificio Istituto Biblico (Rzym, Watykan) }\end{array}$ \\
\hline ojciec Jerzy Tomziński OSPPE & $\begin{array}{l}\text { Pontificia Universitas Gregoriana } \\
\text { (Rzym, Watykan) }\end{array}$ \\
\hline
\end{tabular}

Źródło: P. Nitecki, Biskupi Kościoła w Polsce. Stownik biograficzny, Warszawa 1992;

K.R. Prokop, Biskupi Kościola katolickiego w III Rzeczpospolitej. Leksykon biograficzny,

Kraków 1998 oraz wybrane prace monograficzne poświęcone polskim biskupom.

* W badanym okresie Petersburg należał do Rosji.

** W badanym okresie Lwów należał do Polski.

*** W badanym okresie Wrocław należał do Niemiec.

**** $\mathrm{W}$ badanym okresie Wilno należało do Polski. 


\section{Doświadczenie pasterskie - pokolenie sakry biskupiej (urzędu wyższego przełożonego zakonnego)}

Drugie kryterium odnosi się do wymiaru praktycznego przygotowania do Soboru, a więc doświadczenia pasterskiego polskich ojców soborowych. Pod pojęciem pokolenia sakry biskupiej (urzędu wyższego przełożonego zakonnego) rozumiemy przedział czasowy, w którym otrzymali oni święcenia biskupie lub objęli urząd wyższego przełożonego zakonnego. Analiza biogramów poszczególnych hierarchów pozwala na wyodrębnienie trzech grup. Przyjęty podział związany jest ściśle z przemianami społeczno-politycznymi w Polsce i nawiązuje do obowiązującej periodyzacji:

1) sakra biskupia (urząd wyższego przełożonego zakonnego) do 1945 roku;

2) sakra biskupia (urząd wyższego przełożonego zakonnego) w latach 1946-1955;

3) sakra biskupia (urząd wyższego przełożonego zakonnego) w latach 1956-1965.

Do pierwszego pokolenia sakry należą dostojnicy, którzy otrzymali święcenia biskupie bądź objęli urząd wyższego przełożonego zakonnego do końca 1945 roku. Są to hierarchowie, których kariera duchowna związana jest ściśle $\mathrm{z}$ okresem dwudziestolecia międzywojennego i czasem drugiej wojny światowej. Święcenia kapłańskie przyjęli w ostatnich latach niewoli bądź na progu niepodległości. W Drugiej Rzeczpospolitej osiągnęli wysokie urzędy kościelne, których zwieńczeniem była nominacja biskupia. Należeli więc do ścisłej elity kościelnej dwudziestolecia międzywojennego. Byli to: biskup Franciszek Barda (sakra w 1931 r.), arcybiskup Józef Gawlina (1933) oraz biskup Juliusz Bieniek (1937).

Drugą grupę stanowią dostojnicy, którzy otrzymali nominacje biskupie lub objęli urząd wyższego przełożonego zakonnego w latach 19461955. Święcenia kapłańskie i pracę duszpasterską rozpoczęli w niepodległej już Polsce. Zdobyte wówczas doświadczenie miało fundamentalne znaczenie dla ich dalszych postaw i dokonywanych wyborów. Natomiast sakrę biskupią otrzymali w warunkach rodzącej się nowej rzeczywistości społeczno-politycznej zdominowanej przez komunistów. Ich posługa biskupia przypadała zatem na czas narastającego napięcia na linii państwo-Kościół, którego eskalacją było uwięzienie kardynała Stefana Wyszyńskiego (1953-1956). Jednocześnie coraz trudniejsze warunki - 
z uwagi na represje i szykany władz partyjno-państwowych - towarzyszyły samej pracy duszpasterskiej. W skład tej grupy wchodziło 21 hierarchów, przy czym aż 10 z nich otrzymało sakrę w latach 1946-1947, a więc $\mathrm{W}$ fazie początkowej montowania systemu komunistycznego, kiedy Kościół katolicki cieszył się jeszcze umiarkowanym poziomem swobód $^{21}$. Do najbardziej wyrazistych postaci tego pokolenia sakry należą: kardynał Stefan Wyszyński (święcenia biskupie w 1946 r.), ordynariusz chełmiński biskup Kazimierz Józef Kowalski (1946), sekretarz generalny Konferencji Episkopatu Polski biskup Zygmunt Choromański (1946), ordynariusz łódzki biskup Michał Klepacz (1947). W kolejnych latach liczba święceń biskupich zdecydowanie zmalała, co wiązało się $\mathrm{z}$ ingerencjami i przeszkodami czynionymi przez komunistów. W 1948 roku miała miejsce tylko 1 sakra biskupia, w 1949 roku - 2, w 1950 roku - 2, w 1951 roku - 1, w 1952 roku - 3, w 1954 roku - 2. W roku 1955 w ogóle nie wyświęcono żadnego z polskich hierarchów. W tej najtrudniejszej fazie istnienia Kościoła w Polsce święcenia biskupie przyjął między innymi ordynariusz lubelski biskup Piotr Kałwa (1949), przyszły ordynariusz katowicki biskup Herbert Bednorz (1950), późniejszy metropolita poznański arcybiskup Antoni Baraniak SDB (1951), ordynariusz włocławski biskup Antoni Pawłowski (1952) oraz późniejszy metropolita wrocławski arcybiskup Bolesław Kominek (1954). Do grupy tej przynależy również ojciec Augustyn Ciesielski OCist., który w 1953 roku został prezesem Kongregacji Polskiej Zakonu Cysterskiego ${ }^{22}$.

Trzecia grupa to pokolenie sakry biskupiej (urzędu wyższego przełożonego zakonnego), którego przedstawiciele otrzymali nominacje w latach 1956-1965. Przełom październikowy i objęcie rządów przez Władysława Gomułkę zapoczątkowało zmianę polityki wyznaniowej. Kościół katolicki w pierwszych latach po „odwilży październikowej” uzyskał szereg ustępstw. Dzięki wielu nominacjom biskupim - przede wszystkim sufraganów - prymas Stefan Wyszyński dokonał „uzupełnienia" episkopatu ${ }^{23}$. Młodzi hierarchowie wywodzili się spośród księży, którzy otrzymali święcenia kapłańskie jeszcze przed wybu-

${ }^{21}$ A. D u d e k, R. Gry z, Komuniści i Kościół w Polsce (1945-1989), Kraków 2003, s. 13-27.

22 Augustyn Ciesielski. Dziedzictwo cystersów. Prace zebrane, red. M. S t a r z y ń s k i, M. Z d a n e k, Kraków 2013, s. 30-31.

23 J. Ż a r y n, Dzieje Kościoła katolickiego w Polsce (1944-1989), Warszawa 2003, s. $164 \mathrm{n}$. 
chem drugiej wojny światowej, w jej trakcie lub tuż po jej zakończeniu. Dla wielu z nich początek kapłaństwa łączył się z dramatem drugiej wojny światowej, później świadomie przeżywali montaż systemu komunistycznego i jego pierwszy kryzys. Jednocześnie - jako osobom młodym - towarzyszył im entuzjazm i zaangażowanie w działalność społeczną Kościoła. Do grupy tej należało aż 39 hierarchów. Wyraźnie wyodrębnić można dwie kulminacje nominacji biskupich. Pierwsza obejmuje lata 1957-1959. W tym okresie sakrę przyjęło aż 16 dostojników: w 1957 roku - 3, w 1958 roku - 6, w 1959 roku - 7. W latach 1960-1961 nastąpił nieznaczny spadek święceń biskupich - udzielono ich tylko 7. Od 1962 roku datuje się ponowny wzrost, co niewątpliwie łączyć należy z intensywnymi przygotowaniami duszpasterskimi do Soboru Watykańskiego II. W 1962 roku sakrę otrzymało 6 biskupów, podobnie w roku 1963, w 1964 roku - 3, w 1965 roku - 1. Do najbardziej znaczących hierarchów, którzy weszli w tym czasie do episkopatu, wymienić należy: przyszłego metropolitę krakowskiego biskupa Karola Wojtyłę (1958), późniejszego ordynariusza gorzowskiego biskupa Wilhelma Plutę (1958), metropolitę poznańskiego biskupa Jerzego Strobę (1958), czy ordynariusza koszalińsko-kołobrzeskiego biskupa Ignacego Jeża (1960). Natomiast w okresie Soboru Watykańskiego II święcenia biskupie przyjęli między innymi ordynariusz tarnowski biskup Jerzy Ablewicz (1962), przyszły sekretarz generalny Episkopatu Polski biskup Bronisław Dąbrowski FDP (1962), sufragan łódzki biskup Bohdan Bejze (1963), sufragan krakowski biskup Jan Pietraszko (1963), późniejszy ordynariusz włocławski biskup Jan Zaręba (1963), delegat Prymasa Polski do opieki nad emigracją i uchodźstwem polskim biskup Władysław Rubin (1964). Grupę uzupełniają dwaj wyżsi przełożeni zakonni - kolejni generałowie paulinów - ojciec Ludwik Nowak OSPPE (1957) oraz ojciec Jerzy Tomziński OSPPE (1963).

Podsumowując, wskazać należy, że podczas obrad Soboru Watykańskiego II wśród biskupów ordynariuszy dominowało pokolenie sakry (urzędu wyższego przełożonego zakonnego) 1945-1955. Reprezentowało je aż $12(63,2 \%)$ spośród 19 ordynariuszy. To oni mieli też - ze strony polskich ojców soborowych - największy wpływ na przebieg dyskusji w auli. Z kolei wśród biskupów sufraganów dominowało pokolenie najmłodsze (1956-1965), stanowiąc aż 33 (75\%) spośród 44. Nie odgrywający w praktyce większej roli wyżsi przełożeni zakonni 
przynależeli odpowiednio do pokolenia 1946-1955 - 1 przełożony (33,3\%) oraz 1956-1965 - 2 przełożonych (66,7\%). Liczebnie wśród wszystkich polskich ojców soborowych największy udział posiadali przedstawiciele pokolenia sakry (urzędu wyższego przełożonego zakonnego) 1956-1965. Przynależało do niego aż 41 (62,1\%) z 66 wszystkich polskich ojców soborowych. Do pokolenia 1946-1955 zaliczyć można 22 hierarchów $(33,3 \%)$, a do najstarszego - przed 1945 rokiem - tylko 3 (4,6\%).

Tab. 3. Poszczególne kategorie polskich ojców soborowych według przynależności do pokolenia sakry (urzędu wyższego przełożonego zakonnego)

\begin{tabular}{|l|c|c|c|}
\hline \multicolumn{1}{|c|}{ Kategoria } & $\begin{array}{c}\text { pokolenie } \\
\text { sakry } \\
\text { do 1945 r. }\end{array}$ & $\begin{array}{c}\text { pokolenie } \\
\text { sakry } \\
\mathbf{1 9 4 6 - 1 9 5 5}\end{array}$ & $\begin{array}{c}\text { pokolenie } \\
\text { sakry } \\
\mathbf{1 9 5 6 - 1 9 6 5}\end{array}$ \\
\hline A. Biskupi ordynariusze & 1 & 12 & 6 \\
\hline $\begin{array}{l}\text { B. Biskupi sufragani } \\
\text { i rezydujący w Rzymie }\end{array}$ & 2 & 9 & 33 \\
\hline C. Wyżsi przełożeni zakonni & 0 & 1 & 2 \\
\hline Lącznie (A+B+C) & $\mathbf{3}$ & $\mathbf{2 2}$ & $\mathbf{4 1}$ \\
\hline
\end{tabular}

Źródło: P. Nitecki, Biskupi Kościoła w Polsce. Stownik biograficzny, Warszawa 1992; K.R. Prokop, Biskupi Kościota katolickiego w III Rzeczpospolitej. Leksykon biograficzny, Kraków 1998 oraz wybrane prace monograficzne poświęcone polskim biskupom. 
Wykres 3. Liczba polskich ojców soborowych według godności oraz przynależności do pokolenia sakry (urzędu wyższego przełożonego zakonnego)

pokolenie sakry

1956-1965

pokolenie sakry

1945-1955

pokolenie sakry
do 1945 roku

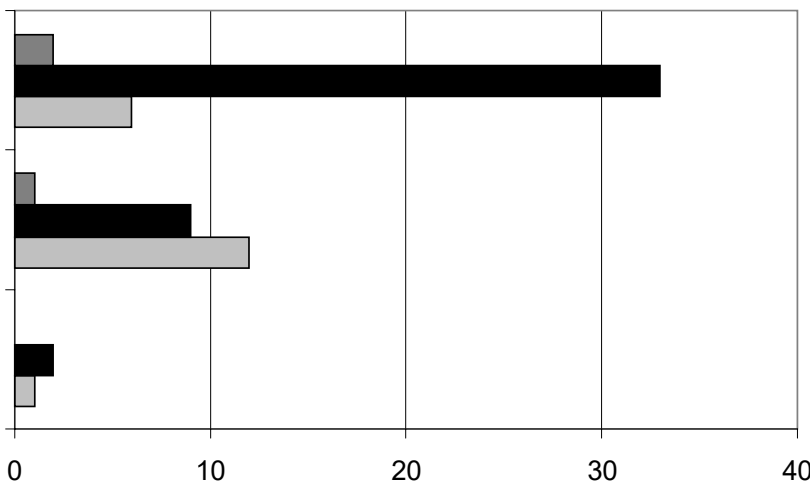

$\square$ Biskupi ordynariusze

- Biskupi sufragani i rezydujący w Rzymie

$\square$ Wyżsi przełożeni zakonni

Wykres 4. Polscy ojcowie soborowi według przynależności do pokolenia sakry (urzędu wyższego przełożonego zakonnego)

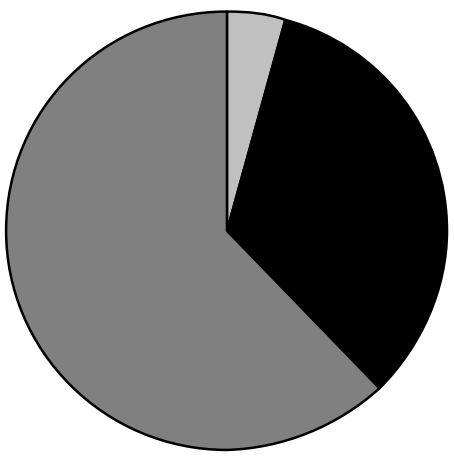

$\square$ pokolenie sakry do 1945 roku

pokolenie sakry 1945-1955

$\square$ pokolenie sakry 1956-1965 


\section{Udzial w obradach soborowych}

Trzecie analizowane kryterium rozumiane jest jako fizyczna obecność dostojnika kościelnego podczas czterech kolejnych sesji obrad soborowych odbywających się w latach $1962-1965^{24}$. Z uwagi na specyficzne warunki funkcjonowania hierarchii Kościoła katolickiego w PRL - narażonej na bezprawne ograniczenia praw i swobód obywatelskich - przyjęto interpretację rozszerzającą, pozwalającą uznać również częściowy, niepełny udział jako obecność w czasie danej sesji soborowej. Przypadki takiej częściowej obecności na poszczególnych sesjach nie były czymś odosobnionym. Wynikały one najczęściej z celowego opóźniania procedur administracyjnych związanych z wydawaniem paszportów, zdarzały się jednak i przypadki losowe, wynikające z choroby bądź nagłej konieczności pozostania lub powrotu do diecezji. Podajmy tylko kilka takich przykładów.

W uroczystej inauguracji Soboru Watykańskiego II w dniu 11 października 1962 roku wzięło udział tylko 18 polskich biskupów ${ }^{25}$. Kolejnych ośmiu przybyło na I sesję z dużym, nawet miesięcznym opóźnieniem. Byli to biskupi: Piotr Kałwa, Jerzy Ablewicz, Wilhelm Pluta, Karol Pękala, Lucjan Bernacki, Jan Jaroszewicz, Henryk Strąkowski i Ignacy Jeż ${ }^{26}$.

Z kolei na II sesję spóźnił się biskup Stefan Bareła i biskup Karol Wojtyła, który dotarł do Rzymu 7 października 1963 roku. Dopiero na

\footnotetext{
${ }^{24}$ Zagadnienie to zostało omówione w artykułach: K. W o j ty $\nmid$ a, Udział biskupów polskich $w$ Soborze Watykańskim II, „Wiadomości Archidiecezjalne Warszawskie” 1971, nr 53 (5), s. 40-46; J. K ł o c z o w s k i, Les évêques polonais et le Concile Vatican II, [w: Le Douxième Concile du Vatican (1959-1965). Actes du Colloque organié par l'École Française de Rome collab. avec l'Université de Lille III, l'Istituto per a Scienze Religieuse de Bologne et de Dipartamento di Studio Storici del Medioevo e dell'eta contemporanea de l'Univ. di Roma La Sapienza (Rome, 28-30 mai 1986), Roma 1989, s. 165-177; K. B i e l a w n y, Udziat biskupów polskich w obradach Soboru Watykańskiego II, „Studia Ełckie" 2009, nr 11, s. 103-122. Jedyną monografią obejmującą wszystkich polskich biskupów - uczestników Soboru Watykańskiego II - jest praca: P. R u t k o w s k i, Polscy biskupi jako ojcowie Soboru Watykańskiego II, Warszawa 2014.

${ }^{25}$ P. R u t k o w s k i, Polscy biskupi jako ojcowie Soboru Watykańskiego II, s. 87.

26 Archiwum Archidiecezjalne Warszawskie, Sekretariat Prymasa Polski, Protokoły Komisji Głównej Episkopatu Polski, II 4/18, k. 1-2, Protokół Komisji Głównej Episkopatu Polski, Warszawa, 8 stycznia 1963 r.; W. W ó j c i k, Zagadnienia organizacyjne i proceduralne podczas I sesji Soboru Watykańskiego II, „Prawo Kanoniczne. Kwartalnik Prawno-Historyczny" 5/3-4, 1962, s. 62.
} 
początku listopada 1963 roku na Sobór przybyli biskupi: Walenty Wójcik, Edward Muszyński, Wacław Wycisk, Kazimierz Majdański, a w połowie tego miesiąca biskup Lech Kaczmarek. Wcześniej do kraju musiał powrócić biskup Henryk Grzondziel ${ }^{27}$.

Podobne problemy - sygnalizowane w protokołach kolejnych konferencji - występowały na III sesji soborowej. W połowie tej sesji do kraju wrócili biskupi Jan Wosiński i Stanisław Jakiel. W tym czasie ich miejsce przyjechali Antoni Pawłowski, Piotr Dudziec i Bolesław Taborski. Dopiero pod koniec sesji przybył biskup Julian Groblicki ${ }^{28}$.

IV sesja Soboru Watykańskiego II rozpoczęła się bez biskupów Jerzego Modzelewskiego i Jana Zaręby, którzy dotarli do Rzymu pod koniec września 1965 roku. Natomiast dopiero na początku października 1965 roku przyjechali biskupi Wacław Majewski i Jan Fondaliński oraz ojciec Jerzy Tomziński OSPPE. Pod koniec października i na początku listopada 1965 roku do kraju wrócili biskupi Bernard Czapliński, Jan Kulik, Lech Kaczmarek, Wincenty Urban, Kazimierz Majdański i Bolesław Taborski. Jeszcze później wyjechał do Polski biskup Jan Pietraszko. W tym czasie do Rzymu udali się biskupi: Jerzy Ablewicz, Edmund Nowicki, Karol Pękala, Stanisław Jakiel. Jeszcze później do Wiecznego Miasta przybyła grupa biskupów, w skład której wchodzili: Antoni Pawłowski, Julian Groblicki, Zygfryd Kowalski, Paweł Latusek i Tadeusz Szwagrzyk. Już w drugiej połowie listopada 1965 roku do kraju powrócili biskupi Jan Fondaliński i Jan Obłąk, natomiast jako ostatni przybyli do Rzymu Józef Drzazga i Bohdan Bejze ${ }^{29}$.

Polscy ojcowie soborowi, mimo wielu przeszkód czynionych im ze strony władz partyjno-państwowych, stanowili znaczącą reprezentację spośród episkopatów państw Europy Środkowo-Wschodniej. Podczas I sesji, jesienią 1962 roku, do Rzymu przyjechało 16 biskupów

\footnotetext{
${ }^{27}$ Interesujące założenia dotyczące ,,polityki paszportowej” wobec polskich biskupów przyjął przed II sesją soborową Wydział I Departamentu IV Ministerstwa Spraw Wewnętrznych: Sobór oczami polskich komunistów. Sobór Watykański II w świetle dokumentów MSW i MSZ, wstęp, wybór i oprac. W. K u c ha r s k i, D. M i s i e j u k, Warszawa 2017, s. 210-212. Kwestie te rozważane są również w książce Wojciech K u chars ki ego, Komuniści $i$ Watykan. Polityka komunistycznej Polski wobec Stolicy Apostolskiej 1945-1974, Warszawa 2019, s. 241 i n.

28 M. B i ałkows ki, Protokoły konferencji polskich ojców soborowych. Zbiór dokumentów 1962-1965, s. 421-547.

${ }^{29}$ P. R u t k o w s k i, Polscy biskupi jako ojcowie Soboru Watykańskiego II, s. 240.
} 
ordynariuszy, 9 biskupów sufraganów, 2 wyższych przełożonych zgromadzeń zakonnych oraz 1 biskup rezydujący w Rzymie. Kościół w Polsce reprezentowało łącznie 28 ojców soborowych. W II sesji uczestniczyło 10 biskupów ordynariuszy, 19 biskupów sufraganów, 1 biskup rezydujący w Rzymie, 1 wyższy przełożony zakonny, łącznie 31 ojców soborowych. Jesienią 1964 roku - na III sesję - władze PRL udzieliły zgody na wyjazd 15 biskupom ordynariuszom i 17 biskupom sufraganom. Obecnych było również 2 biskupów rezydujących w Rzymie. Zatem grupa polskich ojców soborowych liczyła 34 hierarchów. W czasie IV sesji brało udział 15 biskupów ordynariuszy, 30 biskupów sufraganów, 1 biskup rezydujący w Rzymie oraz 2 wyższych przełożonych zakonnych. Była to najliczniejsza delegacja składająca się w sumie z 48 dostojników ${ }^{30}$.

Udziału w obradach nie wzięli z uwagi na stan zdrowia lub podeszły wiek: emerytowany ordynariusz łódzki arcybiskup Włodzimierz Jasiński (ukończone 89 lat), ordynariusz katowicki biskup Stanisław Adamski (ukończone 87 lat), sufragan przemyski biskup Wojciech Tomaka (ukończone 87 lat), sufragan łódzki biskup Kazimierz Tomczak (ukończone 79 lat), ordynariusz sandomierski biskup Jan Kanty Lorek (ukończone 76 lat) oraz sufragan częstochowski biskup Stanisław Czajka ${ }^{31}$.

Ze względów politycznych nie mógł uczestniczyć w I sesji soborowej ordynariusz kielecki biskup Czesław Kaczmarek. Jego śmierć pod koniec sierpnia 1963 roku ostatecznie zakończyła trudną sytuację samego hierarchy i problem zarządzania diecezją kielecką ${ }^{32}$. Spośród innych biskupów ordynariuszy i rządców diecezji paszportu na wyjazd do Rzymu nie otrzymali i nie uczestniczyli w żadnej z sesji soborowych: ordynariusz siedlecki biskup Ignacy Świrski; wikariusz kapitulny archidiecezji wileńskiej z siedzibą w Białymstoku, a następnie administrator

\footnotetext{
30 Album Soborowy, wstęp kard. S. W y s z y ń s k i, ilustracje J. W a 1 k e r, kronika bp B. B e j z e, Poznań-Warszawa 1971, s. 71-72; B. B e j z e, Kronika Soboru Watykańskiego II, Częstochowa 2000, s. 94-97.

31 AAW, SPP, Watykan, II 17/323, k. 203, Pismo biskupa sandomierskiego Jana Kantego Lorka do Prymasa Polski kardynała Stefana Wyszyńskiego, Sandomierz, 19 marca $1962 \mathrm{r}$.

${ }^{32}$ R. G r y z, Biskup kielecki Czestaw Kaczmarek w starciu z komunistycznym totalitaryzmem, „Kieleckie Studia Teologiczne” 2005, nr 4, s. 199-226; J. Ś l e d z i a n o w s k i, Ksiądz Czesław Kaczmarek. Biskup kielecki 1895-1963, Kielce 2008, s. 523 i n.
} 
apostolski biskup Adam Sawicki; wikariusz kapitulny archidiecezji lwowskiej z siedzibą w Lubaczowie ksiądz infułat Jan Nowicki; administrator apostolski diecezji pińskiej z siedzibą w Drohiczynie ksiądz infułat Michał Krzywicki. Również - z powodu represji władz komunistycznych - nie uczestniczyli w obradach soborowych: sufragan archidiecezji wileńskiej z siedzibą w Białymstoku biskup Władysław Suszyński; sufragan sandomierski biskup Piotr Gołębiewski ${ }^{33}$; sufragan tarnowski biskup Michał Blecharczyk oraz sufragan diecezji pińskiej z siedzibą w Drohiczynie biskup Władysław Jędruszuk ${ }^{34}$.

Natomiast obecność na wszystkich czterech sesjach Soboru Watykańskiego II - a więc uczestnictwo w całości obrad soborowych stało się udziałem tylko dziesięciu polskich ojców soborowych:

1) Prymasa Polski, metropolity gnieźnieńskiego i warszawskiego, kardynała Stefana Wyszyńskiego;

2) metropolity poznańskiego arcybiskupa Antoniego Baraniaka SDB;

3) wikariusza kapitulnego archidiecezji krakowskiej biskupa Karola Wojtyły, od 1964 roku arcybiskupa metropolity krakowskiego;

4) ordynariusza lubelskiego biskupa Piotra Kałwy;

5) ordynariusza łódzkiego biskupa Michała Klepacza;

6) ordynariusza chełmińskiego biskupa Kazimierza Józefa Kowalskiego;

7) ordynariusza włocławskiego biskupa Antoniego Pawłowskiego;

8) biskupa rezydencjonalnego w Opolu Franciszka Jopa, specjalnego delegata Prymasa Polski;

9) sufragana katowickiego biskupa Herberta Bednorza, koadiutora cum iure successionis ordynariusza katowickiego biskupa Stanisława Adamskiego;

10) biskupa rezydencjonalnego w Gdańsku Edmunda Nowickiego, koadiutora sedi datus ordynariusza gdańskiego biskupa Carla Marii Spletta, od 1964 roku ordynariusza gdańskiego ${ }^{35}$.

\footnotetext{
${ }^{33}$ A. W a r s o, Trudności paszportowe bpa Piotra Gotębiowskiego, „Kronika Diecezji Radomskiej" 2005, nr 14 (4), s. 643-661.

${ }^{34}$ K. R. Prok op, Pasterze $i$ rządcy diecezji mińskiej, pińskiej $i$ drohiczyńskiej, Drohiczyn 2006, s. 250; Ks. bp Władysław Jędruszuk (1918-1994): pierwszy pasterz Diecezji Drohiczyńskiej. XX rocznica utworzenia Diecezji Drohiczyńskiej, red. M. B o g u s z e w s k i, Z. R o s t k ow s k i, S. U l a c z y k, Drohiczyn-Łosice 2011. ${ }^{35}$ Karol W o j t y $ł$ a w artykule: Udział biskupów polskich $w$ Soborze Watykańskim II, „Wiadomości Archidiecezjalne Warszawskie” 1971, nr 53 (5), s. 42, pomija biskupa
} 
Udział procentowy biskupów ordynariuszy wśród wszystkich polskich ojców soborowych - w poszczególnych sesjach - przestawiał się następująco: I - 57,1\%; II - 32,3\%; III - 44,1\%; IV - 31,3\%. Przytoczone powyżej dane potwierdzają tendencję - wynikającą z dokonywanych przez aparat partyjno-państwowy prób wywierania wpływu na skład oraz liczebność polskich ojców soborowych - polegającą na przyznawaniu paszportów biskupom sufraganom przy jednoczesnym odmawianiu tego prawa biskupom ordynariuszom. Działaniom takim Episkopat Polski przeciwstawił się - jeszcze przed I sesją soborową przyjmując zasadę, że pierwszeństwo w wyjeździe na Sobór Watykański II mają biskupi ordynariusze, a odmowa wydania im paszportu skutkuje również wstrzymaniem się od wyjazdu do Rzymu przez sufragana $^{36}$. Drugim kryterium było członkostwo w Komisji Soborowej Episkopatu Polski oraz jej podkomisjach ${ }^{37}$. Od II sesji - w przypadku, gdy nie mógł wyjechać na Sobór ordynariusz - prawo do złożenia Prymasowi Polski pisemnej kandydatury udzielano sufraganom ${ }^{38}$.

Znaczące zwiększenie liczby polskich ojców soborowych podczas IV sesji należy natomiast tłumaczyć świadomością końca prac soborowych oraz swoistą determinacją w staraniach o wyjazd. Udział w Soborze Watykańskim II był bowiem dla każdego polskiego biskupa

Edmunda Nowickiego. Również w publikacji Roberta S k r z y p c z a k a, Karol Wojtyła na Soborze Watykańskim II. Zbiór wystapień, Warszawa 2011, s. 20, zaistniała podobna pomyłka. Wynika to zapewne z faktu, iż osoba biskupa Edmunda Nowickiego nie była aż do marca 1964 r. zamieszczana w spisie polskich dostojników, ale znajdowała się w osobnej rubryce utworzonej dla biskupów gdańskich. Zmiana nastąpiła po zgonie ordynariusza gdańskiego biskupa Carla Marii Spletta. Natomiast w podobnym wykazie zamieszczonym w tekście Jana W a 1 k u s z a, Drugi Sobór Watykański - próba kontekstualnej interpretacji historycznej, „Colloquia Theologica Ottoniana” 2013, nr 1, s. 28, nie uwzględniono biskupa Franciszka Jopa. Z kolei Piotr R u t k o w s k i w książce Polscy biskupi jako ojcowie Soboru Watykańskiego II, Warszawa 2014, s. 283, podaje tylko ogólną liczbę 10 hierarchów, nie wymieniając ich nazwisk. Ostateczna pełna lista zmieszczona jest w pracy Michała B i a ł k o w s k i e g o, Wokót Soboru Watykańskiego II. Studia i szkice, Toruń 2016, s. 49.

${ }^{36}$ AAW, SPP, Protokoły Konferencji Plenarnej Episkopatu Polski, II 4/211, k. 17, Protokół 82. Konferencji Plenarnej Episkopatu Polski, Warszawa, 18 czerwca 1964 r.; AAW, SPP, Protokoły Konferencji Plenarnej Episkopatu Polski, II 4/217, k. 14, Protokół 88. Konferencji Plenarnej Episkopatu Polski, Warszawa, 23 czerwca 1965 r.

${ }^{37}$ P. R u t k o w s k i, Polscy biskupi jako ojcowie Soboru Watykańskiego II, s. 183.

38 AAW, SPP, Protokoły Konferencji Plenarnej Episkopatu Polski, II 4/204, k. 114, Protokół 75. Konferencji Plenarnej Episkopatu Polski, Warszawa, 13 marca 1963 r. 
wydarzeniem wyjątkowym i niepowtarzalnym. Co więcej, w liczbie tej dominującą grupą stali się biskupi sufragani. Wzrost liczby biskupów sufraganów przybyłych na Sobór jesienią 1965 roku (30) w stosunku do jesieni 1964 roku (17) osiągnął wielkość 43,3\%. Warto zauważyć również inną tendencję. Spośród 30 biskupów sufraganów uczestniczących w IV sesji soborowej aż 15 (50\%) to biskupi, którzy otrzymali sakrę w latach 1962-1965, a więc hierarchowie o bardzo krótkim doświadczeniu posługi biskupiej. Jednocześnie grupa ta obejmuje aż 88,2\% wszystkich biskupów sufraganów o najkrótszym doświadczeniu posługi biskupiej. Poza nią znajdują się przypadki biskupa Bronisława Dąbrowskiego FDP, który nie otrzymał paszportu na wyjazd w 1965 roku, oraz Władysława Jędruszuka, któremu odmawiano prawa do wyjazdu na Sobór Watykański II.

Mimo polityki władz partyjno-państwowych ograniczającej wyjazdy hierarchów na Sobór Watykański II, zauważyć można - w okresie czterech kolejnych sesji - tendencję wzrostu liczby polskich ojców soborowych. Najwyraźniej widoczna jest ona w przypadku sesji skrajnych (I i IV), z 28 do 48 ojców soborowych - wzrost aż o 41,7\%. Odnosi się jednak przede wszystkim do grupy biskupów sufraganów, natomiast liczba biskupów ordynariuszy - na przestrzeni kolejnych czterech sesji przyjmuje zbliżone wielkości (odpowiednio: 16, 10, 15 i 15).

Tab. 4. Polscy ojcowie soborowi

według udziału w poszczególnych sesjach Soboru Watykańskiego II

A. Biskupi ordynariusze

\begin{tabular}{|l|c|c|c|c|}
\hline \multicolumn{1}{|c|}{ Imię i nazwisko biskupa } & I sesja & II sesja & III sesja & IV sesja \\
\hline kardynał Stefan Wyszyński & + & + & + & + \\
\hline arcybiskup Antoni Baraniak & + & + & + & + \\
\hline arcybiskup Bolesław Kominek & + & - & - & + \\
\hline arcybiskup Karol Wojtyła & + & + & + & + \\
\hline biskup Jerzy Ablewicz & + & - & - & + \\
\hline biskup Franciszek Barda & + & - & - & - \\
\hline biskup Stefan Bareła & - & + & + & + \\
\hline
\end{tabular}




\begin{tabular}{|l|c|c|c|c|}
\hline biskup Czesław Falkowski & - & - & + & + \\
\hline biskup Zdzisław Goliński & + & - & - & - \\
\hline biskup Jan Jaroszewicz & + & - & + & + \\
\hline biskup Franciszek Jop & + & + & + & + \\
\hline biskup Piotr Kałwa & + & + & + & + \\
\hline biskup Michał Klepacz & + & + & + & + \\
\hline biskup Kazimierz J. Kowalski & + & + & + & + \\
\hline biskup Edmund Nowicki & + & + & + & + \\
\hline biskup Antoni Pawłowski & + & + & + & + \\
\hline biskup Wilhelm Pluta & + & - & + & - \\
\hline biskup Bogdan Sikorski & - & - & + & + \\
\hline biskup Tomasz Wilczyński & + & - & + & - \\
\hline Łącznie (A): & 16 & 10 & 15 & 15 \\
\hline
\end{tabular}

B. Biskupi sufragani i rezydujący w Rzymie

\begin{tabular}{|l|c|c|c|c|}
\hline \multicolumn{1}{|c|}{ Imię i nazwisko biskupa } & I sesja & II sesja & III sesja & IV sesja \\
\hline biskup Herbert Bednorz & + & + & + & + \\
\hline biskup Bohdan Bejze & - & - & + & + \\
\hline biskup Lucjan Bernacki & + & - & - & - \\
\hline biskup Juliusz Bieniek & - & - & + & - \\
\hline biskup Zygmunt Choromański & + & - & + & - \\
\hline biskup Bernard Czapliński & - & + & - & + \\
\hline biskup Jan Czerniak & - & + & - & + \\
\hline biskup Bronisław Dąbrowski & - & - & + & - \\
\hline biskup Józef Drzazga & - & + & + & + \\
\hline biskup Piotr Dudziec & - & - & + & - \\
\hline biskup Tadeusz Etter & - & + & - & - \\
\hline
\end{tabular}




\begin{tabular}{|c|c|c|c|c|}
\hline biskup Jan Fondaliński & + & - & - & + \\
\hline biskup Julian Groblicki & - & - & + & + \\
\hline biskup Henryk Grzondziel & - & + & - & + \\
\hline biskup Stanisław Jakiel & - & + & + & + \\
\hline biskup Franciszek Jedwabski & - & - & + & + \\
\hline biskup Ignacy Jeż & + & - & - & - \\
\hline biskup Lech Kaczmarek & - & + & + & + \\
\hline biskup Zygfryd Kowalski & - & - & + & + \\
\hline biskup Jan Kulik & - & + & - & + \\
\hline biskup Józef Kurpas & - & + & - & + \\
\hline biskup Paweł Latusek & - & - & + & + \\
\hline biskup Kazimierz Majdański & - & + & - & + \\
\hline biskup Wacław Majewski & - & + & - & + \\
\hline biskup Jan Mazur & - & + & - & - \\
\hline biskup Jerzy Modzelewski & - & - & - & + \\
\hline biskup Aleksander Mościcki & - & + & - & - \\
\hline biskup Edward Muszyński & - & + & - & - \\
\hline biskup Jan Obłąk & - & + & - & + \\
\hline biskup Karol Pękala & + & - & - & + \\
\hline biskup Jan Pietraszko & - & - & + & + \\
\hline biskup Wacław Skomorucha & - & + & - & + \\
\hline biskup Henryk Strąkowski & + & - & - & - \\
\hline biskup Jerzy Stroba & - & - & - & + \\
\hline biskup Tadeusz Szwagrzyk & - & - & - & + \\
\hline biskup Bolesław Taborski & - & - & + & + \\
\hline biskup Wincenty Urban & - & - & - & + \\
\hline biskup Jan Wosiński & - & - & + & + \\
\hline biskup Walenty Wójcik & + & + & - & - \\
\hline
\end{tabular}




\begin{tabular}{|l|c|c|c|c|}
\hline biskup Andrzej Wronka & + & - & - & + \\
\hline biskup Wacław Wycisk & - & + & + & + \\
\hline biskup Jan Zaręba & - & - & - & + \\
\hline biskup Władysław Rubin & - & - & + & + \\
\hline arcybiskup Józef Gawlina & + & + & + & - \\
\hline Łącznie (B): & 10 & 20 & 19 & 31 \\
\hline
\end{tabular}

C. Wyżsi przełożeni zakonni

\begin{tabular}{|l|c|c|c|c|}
\hline \multicolumn{1}{|c|}{$\begin{array}{c}\text { Imię i nazwisko } \\
\text { wyższego przelożonego }\end{array}$} & I sesja & II sesja & III sesja & IV sesja \\
\hline o. Augustyn Ciesielski OCist & + & + & - & + \\
\hline o. Ludwik Nowak OSPPE & + & - & - & - \\
\hline o. Jerzy Tomziński OSPPE & - & - & - & + \\
\hline Łącznie (C): & 2 & 1 & 0 & 2 \\
\hline
\end{tabular}

\begin{tabular}{|c|c|c|c|c|}
\hline \multirow{2}{*}{ Lącznie (A+B+C) } & I sesja & II sesja & III sesja & IV sesja \\
\cline { 2 - 5 } & 28 & 31 & 34 & 48 \\
\hline
\end{tabular}

Źródło: Album Soborowy, s. 71-72; B. Bejze, Kronika Soboru Watykańskiego II, s. 94-97 oraz opracowania własne. 
Wykres 5. Liczba polskich ojców soborowych według godności oraz udziału w poszczególnych sesjach Soboru Watykańskiego II

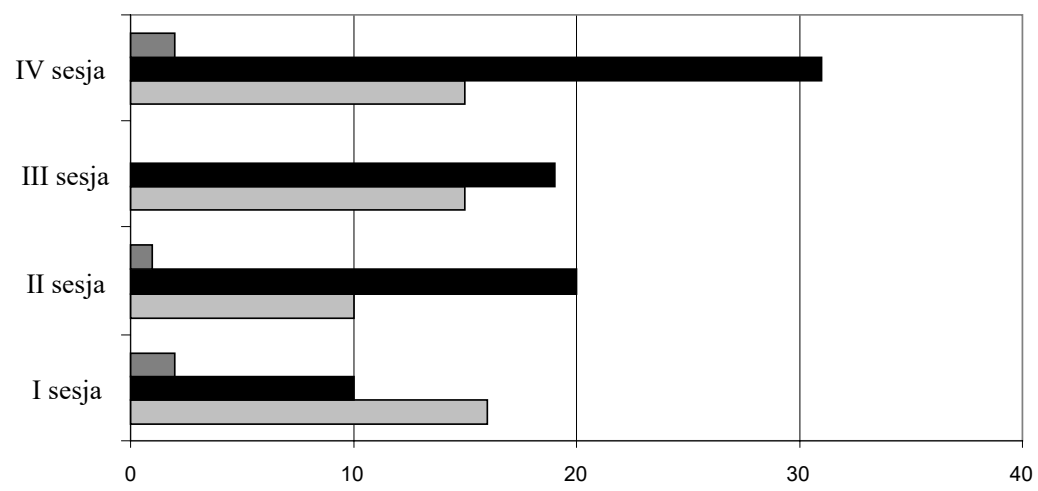

$\square$ Biskupi ordynariusze

Biskupi sufragani i rezydujący w Rzymie

$\square$ Wyżsi przełożeni zakonni

Wykres 6. Polscy ojcowie soborowi według udziału w poszczególnych sesjach Soboru Watykańskiego II

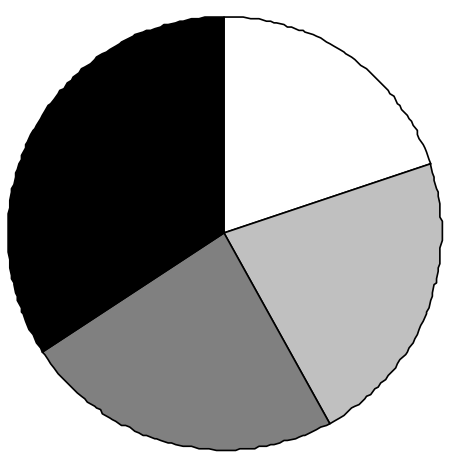

I sesja

II sesja

III sesja

IV sesja 


\section{Aktywność w obradach soborowych}

Kolejnym kryterium związanym z udziałem w Soborze Watykańskim II jest aktywność polskich ojców soborowych w poszczególnych sesjach Soboru. Obiektywnym wskaźnikiem jej pomiaru jest:

1) liczba publicznych wystąpień podczas Kongregacji Generalnych;

2) liczba złożonych pisemnych uwag (animadversiones) do Sekretariatu Generalnego Soboru.

$\mathrm{Na}$ przestrzeni czterech sesji polscy ojcowie soborowi przemawiali 75 razy $^{39}$. Średnio na jednego polskiego ojca soborowego (66) przypadało 1,13 wystąpień w auli soborowej. Natomiast jeśli ograniczymy liczbę ojców soborowych tylko do grupy tych, którzy wygłaszali przemówienia (24) - wówczas na jednego przypadnie średnio 3,12.

Podczas I sesji polscy ojcowie soborowi wypowiadali się 20 razy, w trakcie II - 16 razy, III - 26 razy i IV - 13 razy. Oznacza to, że podczas I sesji polscy ojcowie soborowi wygłosili $26,7 \%$ wszystkich wystapień, podczas II sesji - 21,3\%, podczas III sesji - 34,7\%, a podczas IV sesji $17,3 \%$. W czasie I sesji biskupi ordynariusze występowali 15 razy, a biskupi sufragani i rezydujący w Rzymie -5 . Z kolei podczas II sesji biskupi ordynariusze 12 razy, a sufragani i rezydujący w Rzymie -4 . W czasie III sesji zarówno biskupi ordynariusze, jak i biskupi sufragani występowali najczęściej - odpowiednio 18 i 8 razy. Natomiast w czasie IV sesji - odpowiednio 11 i 2 razy. Kumulacja wystąpień podczas III sesji jest ogólną tendencją charakterystyczną dla wielu innych episkopatów uczestniczących w Soborze Watykańskim II. Tendencja ta odpowiada ponadto dynamice prac soborowych. Zasadnicze przygotowanie redakcyjne większości dokumentów soborowych miało miejsce: pomiędzy II i III sesją soborową (wiosną i latem 1964 r.), podczas III sesji (jesienią 1964 r.) oraz pomiędzy III i IV sesją soborową (wiosną i latem 1965 r.). Ostatnia sesja soborowa miała natomiast charakter finalny, a debaty o charakterze doktrynalno-duszpasterskim w znacznej mierze zastąpiły prace redakcyjne i techniczne związane $\mathrm{z}$ procedurami ostatecznego zatwierdzenia poszczególnych dokumentów soborowych.

39 W pracy J. Ż a r y n, Dzieje Kościoła katolickiego w Polsce (1944-1989), s. 228, podano, że wypowiadali się 76 razy. Z kolei w opracowaniu Sobór oczami polskich komunistów. Sobór Watykański II w świetle dokumentów MSW i MSZ, s. 412, przywołane dane mówią o 58 przemówieniach w auli soborowej oraz 22 wystąpieniach na piśmie bez publicznego wygłaszania. 
Inna zauważana tendencja to dominujący udział wystąpień wygłaszanych przez biskupów ordynariuszy - aż 56 spośród 75, a więc aż 74,7\%. Z kolei 19 wypowiedzi wygłaszanych w auli soborowej przez biskupów sufraganów i rezydujących w Rzymie stanowi tylko 25,3\% wszystkich polskich wystąpień publicznych. Szczególnie ciekawe wyniki pokazują dane dotyczące IV sesji soborowej. Uczestniczyło w niej 15 biskupów ordynariuszy i aż 30 biskupów sufraganów. Biskupi ordynariusze wygłosili 11 przemówień, co daje 0,73 przemówienia na 1 hierarchę. Biskupi sufragani wygłosili dwa przemówienia, co daje tylko 0,06 przemówień na 1 hierarchę. Aktywność polskich biskupów sufraganów podczas IV sesji była więc znikoma i miała wymiar wyłącznie symboliczny. Warto dodać również, że polscy wyżsi przełożeni zakonni nie wygłosili żadnego przemówienia podczas obrad soborowych.

Polskim hierarchą, który najczęściej zabierał głos w auli soborowej, był kardynał Stefan Wyszyński (10 wystąpień $)^{40}$. Kolejne miejsca zajęli: biskup Michał Klepacz (9 wystąpień), arcybiskup Karol Wojtyła (8 wystąpień), arcybiskup Antoni Baraniak SDB (7 wystąpień), biskup Edmund Nowicki (4 wystąpienia), biskup Herbert Bednorz (4 wystąpienia), biskup Franciszek Jop (3 wystąpienia), biskup Kazimierz Józef Kowalski (3 wystąpienia), biskup Antoni Pawłowski (3 wystąpienia), biskup Wilhelm Pluta (3 wystąpienia). Wszyscy wyżej wymienieni poza biskupem Herbertem Bednorzem - byli ordynariuszami bądź rządcami diecezji. Pozostałych 14 polskich hierarchów - wśród których dominowali biskupi sufragani - wygłosiło łącznie 21 przemówień (7 biskupów występowało dwukrotnie, 7 pozostałych wygłosiło pojedyncze mowy) ${ }^{41}$.

Podsumowując, należy stwierdzić, że decydujący aktywny udział w obradach soborowych należał do biskupów ordynariuszy i to przede wszystkim ta grupa była widoczną reprezentacją Kościoła w Polsce na Soborze Watykańskim II. Biskupi ordynariusze wygłosili aż 74,7\% wszystkich przemówień polskich ojców soborowych. Szczególną rolę wśród ordynariuszy odgrywali obecni na Soborze Watykańskim II

\footnotetext{
${ }^{40}$ Ks. Marian R o l a, w artykule, Wkład kard. Stefana Wyszyńskiego w prace Soboru Watykańskiego II, „Warszawskie Studia Teologiczne” III/1985-1990, s. 56, wylicza 11 wystąpień, ale jako pierwsze podaje przemówienie na temat orędzia do wszystkich ludzi, które zostało wygłoszone na III Kongregacji Generalnej 20 października 1962 r. Nie dotyczyło ono jednak ściśle tematyki obrad soborowych.

${ }^{41}$ B. B e j z e, Kronika Soboru Watykańskiego II, s. 101-111.
} 
członkowie Komisji Głównej Episkopatu Polski (kardynał Stefan Wyszyński, arcybiskup Antoni Baraniak SDB, arcybiskup Bolesław Kominek, arcybiskup Karol Wojtyła, biskup Franciszek Jop, biskup Piotr Kałwa, biskup Michał Klepacz) ${ }^{42}$. Łącznie wygłosili oni aż 40 spośród 75 przemówień $(53,3 \%)$.

Tab. 5. Polscy ojcowie soborowi według liczby publicznych wystąpień w auli soborowej podczas poszczególnych sesji Soboru Watykańskiego II

A. Biskupi ordynariusze

\begin{tabular}{|l|c|c|c|c|c|}
\hline \multicolumn{1}{|c|}{ Imię i nazwisko biskupa } & $\begin{array}{c}\text { I } \\
\text { sesja }\end{array}$ & $\begin{array}{c}\text { II } \\
\text { sesja }\end{array}$ & $\begin{array}{c}\text { III } \\
\text { sesja }\end{array}$ & $\begin{array}{c}\text { IV } \\
\text { sesja }\end{array}$ & Lącznie \\
\hline kardynał Stefan Wyszyński & 3 & 2 & 2 & 3 & 10 \\
\hline arcybiskup Antoni Baraniak & 1 & 2 & 2 & 2 & 7 \\
\hline arcybiskup Bolesław Kominek & 1 & - & - & 1 & 2 \\
\hline arcybiskup Karol Wojtyła & 2 & 1 & 3 & 2 & 8 \\
\hline biskup Stefan Bareła & - & - & 1 & 1 & 2 \\
\hline biskup Franciszek Jop & 2 & 1 & - & - & 3 \\
\hline biskup Piotr Kałwa & - & 1 & - & - & 1 \\
\hline biskup Michał Klepacz & 1 & 4 & 2 & 2 & 9 \\
\hline biskup Kazimierz J. Kowalski & 1 & - & 2 & - & 3 \\
\hline biskup Edmund Nowicki & 1 & 1 & 2 & - & 4 \\
\hline biskup Antoni Pawłowski & 2 & - & 1 & - & 3 \\
\hline biskup Wilhelm Pluta & 1 & - & 2 & - & 3 \\
\hline biskup Tomasz Wilczyński & - & - & 1 & - & 1 \\
\hline Łącznie (A): & 15 & 12 & 18 & 11 & 56 \\
\hline
\end{tabular}

${ }^{42}$ AAW, SPP, Protokoły Konferencji Plenarnej Episkopatu Polski, II 4/200, k. 118, Komisje Uzupełnione, 15 marca 1962 r.; AAW, SPP, Protokoły Komisji Głównej Episkopatu Polski, II 4/19, k. 3, Protokół Komisji Głównej, Warszawa, 5 lutego 1964 r. 
B. Biskupi sufragani i rezydujący w Rzymie

\begin{tabular}{|l|c|c|c|c|c|}
\hline \multicolumn{1}{|c|}{ Imię i nazwisko biskupa } & $\begin{array}{c}\text { I } \\
\text { sesja }\end{array}$ & $\begin{array}{c}\text { II } \\
\text { sesja }\end{array}$ & $\begin{array}{c}\text { III } \\
\text { sesja }\end{array}$ & $\begin{array}{c}\text { IV } \\
\text { sesja }\end{array}$ & Lącznie \\
\hline biskup Herbert Bednorz & 1 & 1 & 1 & 1 & 4 \\
\hline biskup Bohdan Bejze & - & - & 2 & - & 2 \\
\hline biskup Lucjan Bernacki & 2 & - & - & - & 2 \\
\hline biskup Józef Drzazga & - & 1 & 1 & - & 2 \\
\hline biskup Zygfryd Kowalski & - & - & 1 & - & 1 \\
\hline biskup Paweł Latusek & - & - & 1 & - & 1 \\
\hline biskup Kazimierz Majdański & - & - & - & 1 & 1 \\
\hline biskup Jan Mazur & - & 2 & - & - & 2 \\
\hline biskup Jan Pietraszko & - & - & 1 & - & 1 \\
\hline biskup Andrzej Wronka & 1 & - & - & - & 1 \\
\hline arcybiskup Józef Gawlina & 1 & - & 1 & - & 2 \\
\hline Łącznie (B): & 5 & 4 & 8 & 2 & 19 \\
\hline
\end{tabular}

\begin{tabular}{|l|c|c|c|c|c|}
\hline Lącznie (A+B) & $\begin{array}{c}\text { I } \\
\text { sesja }\end{array}$ & $\begin{array}{c}\text { II } \\
\text { sesja }\end{array}$ & $\begin{array}{c}\text { III } \\
\text { sesja }\end{array}$ & $\begin{array}{c}\text { IV } \\
\text { sesja }\end{array}$ & $\begin{array}{c}\text { Lacznie } \\
\text { (I+II+III+IV) }\end{array}$ \\
\cline { 2 - 6 } & 20 & 16 & 26 & 13 & 75 \\
\hline
\end{tabular}

Źródło: B. Bejze, Kronika Soboru Watykańskiego II, s. 100-111; Stefan Kardynat Wyszyński, Prymas Polski, Ojciec Soboru Watykańskiego II 1962-1965. Wybór dokumentów, oprac. S. Wilk SDB, A. Wójcik, Lublin 2013, s. 379-384. 
Wykres 7. Liczba polskich ojców soborowych według godności oraz częstotliwości publicznych wystąpień w auli soborowej podczas poszczególnych sesji Soboru Watykańskiego II

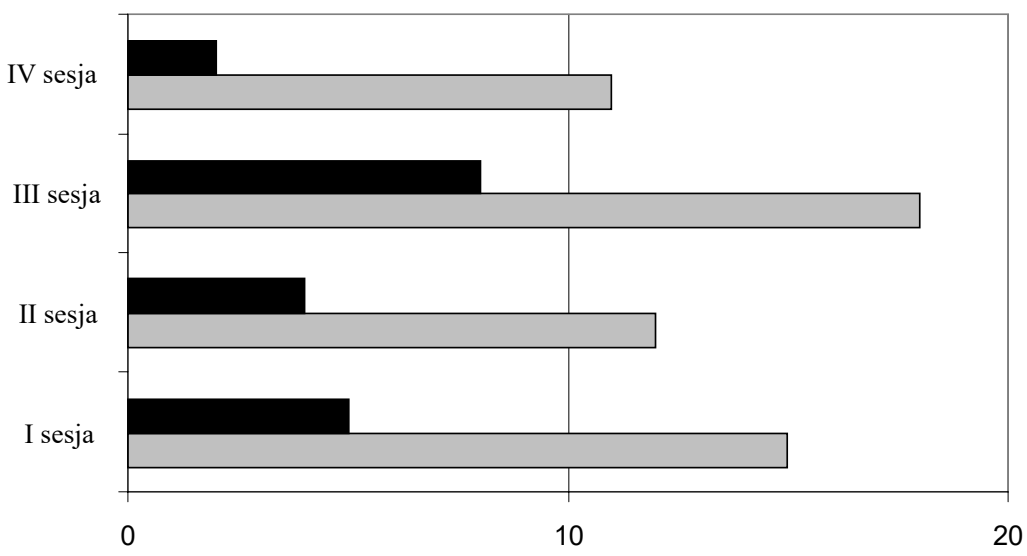

$\square$ Biskupi ordynariusze

- Biskupi sufragani i rezydujący w Rzymie

Wykres 8. Polscy ojcowie soborowi według częstotliwości publicznych wystąpień w auli soborowej podczas poszczególnych sesji Soboru Watykańskiego II

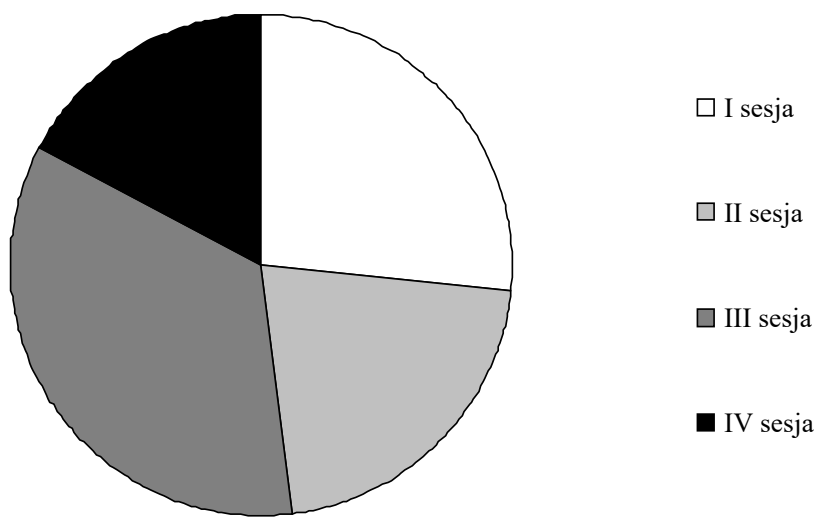


Drugim ważnym miernikiem aktywności polskich ojców soborowych są złożone do Sekretariatu Generalnego Soboru animadversiones pisemne uwagi. Na przestrzeni czterech sesji polscy ojcowie soborowi składali je $105^{43}$. Średnio na jednego polskiego ojca soborowego (66) przypadało 1,59 animadversiones. Natomiast jeśli ograniczymy liczbę ojców soborowych tylko do grupy tych, którzy składali pisemne uwagi (35), wówczas na jednego przypadnie średnio 3,0.

Podczas I sesji polscy ojcowie soborowi składali pisemne uwagi 11 razy, w trakcie II - 35 razy, III - 40 razy i IV - 19 razy. Oznacza to, że podczas I sesji polscy ojcowie soborowi składali 10,5\% wszystkich animadversiones, podczas II sesji - 33,3\%, podczas III sesji - 38,1\%, a podczas IV sesji - 18,1\%. W czasie I sesji biskupi ordynariusze występowali 5 razy, a biskupi sufragani i rezydujący w Rzymie - 6 . Z kolei podczas II sesji biskupi ordynariusze 16 razy, a sufragani i rezydujący w Rzymie - 19. W czasie III sesji zarówno biskupi ordynariusze, jak i biskupi sufragani występowali najczęściej - odpowiednio 17 i 23 razy. Natomiast w czasie IV sesji - odpowiednio 8 i 11 razy. Oznacza to, że podobnie jak w przypadku wystąpień publicznych również największa liczba animadversiones składana była w najbardziej pracowitej fazie prac soborowych.

Odmiennie niż w przypadku wystąpień publicznych, większość animadversiones składali biskupi sufragani i rezydujący w Rzymie aż 59 spośród 105, a więc 56,2\%. Z kolei 46 uwag pisemnych wnoszonych do Sekretariatu Generalnego Soboru przez biskupów ordynariuszy stanowi 43,8\% animadversiones. Największą liczbę uwag biskupi sufragani złożyli podczas III sesji soborowej. Obecnych wówczas 19 przedstawicieli tej grupy hierarchów złożyło 23 pisemne uwagi, co daje 1,21 animadversiones na 1 biskupa sufragana.

Wyjątkowa aktywność biskupów sufraganów w składaniu pisemnych uwag widoczna jest również, gdy przypatrzymy się działaniom podejmowanym przez poszczególnych hierarchów. Absolutnym rekordzistą jest co prawda arcybiskup Karol Wojtyła (15 animadversiones), co wynika z jego wyjątkowej aktywności na Soborze Watykańskim II, a skala aktywności nie pozwala na jakiekolwiek ujęcie porównawcze (złożył aż 32,6\% wszystkich animadversiones wniesionych przez

${ }^{43}$ W przywoływanej już pracy Jana Ż a r y n a, Dzieje Kościoła katolickiego w Polsce (1944-1989), s. 228, utrzymuje, że wypowiadali się na piśmie tylko 56 razy. 
polskich biskupów ordynariuszy) ${ }^{44}$. Jednak miejsce drugie i trzeciej zajmują dwaj sufragani - biskup Michał Blecharczyk (11) i biskup Walenty Wójcik (9). Przypomnijmy, że pierwszy z wymienionych nie uczestniczył w żadnej z czterech sesji soborowych, a pisemne uwagi składał za pośrednictwem innych dostojników. Czwarte miejsce zajęli dwaj hierarchowie, którzy ośmiokrotnie składali uwagi dotyczące przygotowywanych przez Sobór schematów. Byli to arcybiskup Józef Gawlina $^{45}$ i biskup Kazimierz Józef Kowalski. Pozostali hierarchowie złożyli od 4 (biskup Michał Klepacz, Lech Kaczmarek, Jan Kulik) do 1 animadversiones. Ciekawym przypadkiem jest arcybiskup Bolesław Kominek, który będąc obecny na dwóch z czterech sesji soborowych, nie złożył żadnego animadversiones ${ }^{46}$. Dwaj inni wysocy dostojnicy Kościoła w Polsce - kardynał Stefan Wyszyński i arcybiskup Antoni Baraniak SDB - również niezwykle rzadko odwoływali się do tego typu interwencji. Prymas Polski złożył tylko dwukrotnie uwagi pisemne, a metropolita poznański trzykrotnie. Żadnych animadversiones nie złożyli wyżsi przełożeni zakonni.

Podsumowując, należy wskazać, że druga forma aktywności soborowej podejmowana była przede wszystkim przez biskupów sufraganów. Wynikało to zapewne z podstawowych kierunków ,polityki soborowej” wyznaczanej przez samego kardynała Stefana Wyszyńskiego, polegającej między innymi na zlecaniu przygotowania wystąpień publicznych (bardziej efektownych) lepiej przygotowanym i bardziej doświadczonym biskupom ordynariuszom. Z dużym prawdopodobieństwem można również stwierdzić, że przywódca polskiego episkopatu promując w ten sposób najważniejszych hierarchów, starał się włączyć ich w główne nurty debat soborowych oraz relacji międzyepiskopalnych. Z kolei dla wielu biskupów sufraganów złożenie animadversiones do Sekretariatu Generalnego Soboru było często jedynym świadectwem aktywnego uczestnictwa w obradach. Ta forma zaprezentowania stanowiska polskich ojców soborowych również wymagała rzetelnego przygotowania oraz specjalistycznej wiedzy teologicznej.

44 R. S k r z y p c z a k, Karol Wojtyła na Soborze Watykańskim II. Zbiór wystapień, s. 189-198, 214-246, 256-266, 275-281, 292-305, 317-320, 332-352.

45 D. B e d narski, Biskup Józef Gawlina jako opiekun Polaków na emigracji, Katowice 2019.

46 Stefan Kardynat Wyszyński, Prymas Polski, Ojciec Soboru Watykańskiego II 19621965. Wybór dokumentów, s. 378-384. 
Tab. 6. Polscy ojcowie soborowi według liczby złożonych animadversiones podczas poszczególnych sesji Soboru Watykańskiego II

A. Biskupi ordynariusze

\begin{tabular}{|l|c|c|c|c|c|}
\hline \multicolumn{1}{|c|}{ Imię i nazwisko biskupa } & $\begin{array}{c}\text { I } \\
\text { sesja }\end{array}$ & $\begin{array}{c}\text { II } \\
\text { sesja }\end{array}$ & $\begin{array}{c}\text { III } \\
\text { sesja }\end{array}$ & $\begin{array}{c}\text { IV } \\
\text { sesja }\end{array}$ & Lącznie \\
\hline kardynał Stefan Wyszyński & - & 1 & 1 & - & 2 \\
\hline arcybiskup Antoni Baraniak & - & 2 & 1 & - & 3 \\
\hline arcybiskup Karol Wojtyła & 2 & 4 & 5 & 4 & 15 \\
\hline biskup Stefan Bareła & - & 2 & - & - & 2 \\
\hline biskup Zdzisław Goliński & 1 & - & - & - & 1 \\
\hline biskup Franciszek Jop & 1 & - & - & 1 & 2 \\
\hline biskup Piotr Kałwa & - & - & 1 & 1 & 2 \\
\hline biskup Michał Klepacz & - & 2 & 2 & - & 4 \\
\hline biskup Kazimierz J. Kowalski & 1 & 2 & 4 & 1 & 8 \\
\hline biskup Edmund Nowicki & - & 1 & - & - & 1 \\
\hline biskup Antoni Pawłowski & - & 2 & - & - & 2 \\
\hline biskup Wilhelm Pluta & - & - & 2 & - & 2 \\
\hline biskup Bogdan Sikorski & - & - & - & 1 & 1 \\
\hline biskup Tomasz Wilczyński & - & - & 1 & - & 1 \\
\hline Łącznie (A): & 5 & 16 & 17 & 8 & 46 \\
\hline
\end{tabular}

B. Biskupi sufragani i rezydujący w Rzymie

\begin{tabular}{|l|c|c|c|c|c|}
\hline \multicolumn{1}{|c|}{ Imię i nazwisko biskupa } & $\begin{array}{c}\text { I } \\
\text { sesja }\end{array}$ & $\begin{array}{c}\text { II } \\
\text { sesja }\end{array}$ & $\begin{array}{c}\text { III } \\
\text { sesja }\end{array}$ & $\begin{array}{c}\text { IV } \\
\text { sesja }\end{array}$ & Lącznie \\
\hline biskup Herbert Bednorz & 1 & - & 2 & - & 3 \\
\hline biskup Bohdan Bejze & - & - & 1 & - & 1 \\
\hline biskup Lucjan Bernacki & - & - & 1 & - & 1 \\
\hline biskup Michał Blecharczyk & - & 1 & 8 & 2 & 11 \\
\hline
\end{tabular}




\begin{tabular}{|l|c|c|c|c|c|}
\hline biskup Jan Czerniak & - & 1 & - & - & 1 \\
\hline biskup Bronisław Dąbrowski & - & - & 1 & - & 1 \\
\hline biskup Józef Drzazga & - & - & 1 & - & 1 \\
\hline biskup Jan Fondaliński & - & - & - & 1 & 1 \\
\hline biskup Julian Groblicki & - & - & 2 & - & 2 \\
\hline biskup Jan Jaroszewicz & - & 1 & - & - & 1 \\
\hline biskup Ignacy Jeż & - & - & 1 & - & 1 \\
\hline biskup Lech Kaczmarek & - & 1 & 1 & 2 & 4 \\
\hline biskup Jan Kulik & - & 2 & - & 2 & 4 \\
\hline biskup Paweł Latusek & - & - & 1 & - & 1 \\
\hline biskup Jan Mazur & - & 1 & - & - & 1 \\
\hline biskup Jerzy Stroba & - & - & 1 & 1 & 2 \\
\hline biskup Walenty Wójcik & 3 & 6 & - & - & 9 \\
\hline biskup Andrzej Wronka & 1 & - & 1 & 1 & 3 \\
\hline biskup Wacław Wycisk & - & 1 & - & - & 1 \\
\hline biskup Władysław Rubin & - & - & - & 2 & 2 \\
\hline arcybiskup Józef Gawlina & 1 & 5 & 2 & - & 8 \\
\hline Łącznie (B): & 6 & 19 & 23 & 11 & 59 \\
\hline
\end{tabular}

\begin{tabular}{|l|c|c|c|c|c|}
\hline Lącznie (A+B) & $\begin{array}{c}\text { I } \\
\text { sesja }\end{array}$ & $\begin{array}{c}\text { II } \\
\text { sesja }\end{array}$ & $\begin{array}{c}\text { III } \\
\text { sesja }\end{array}$ & $\begin{array}{c}\text { IV } \\
\text { sesja }\end{array}$ & $\begin{array}{c}\text { Lacznie } \\
(\text { I+II+III+IV) }\end{array}$ \\
\cline { 2 - 6 } & 11 & 35 & 40 & 19 & 105 \\
\hline
\end{tabular}

Źródło: Stefan Kardynat Wyszyński, Prymas Polski, Ojciec Soboru Watykańskiego II 1962-1965. Wybór dokumentów, s. 379-384. 
Wykres 9. Liczba polskich ojców soborowych według godności oraz ilości złożonych animadversiones podczas poszczególnych sesji Soboru Watykańskiego II

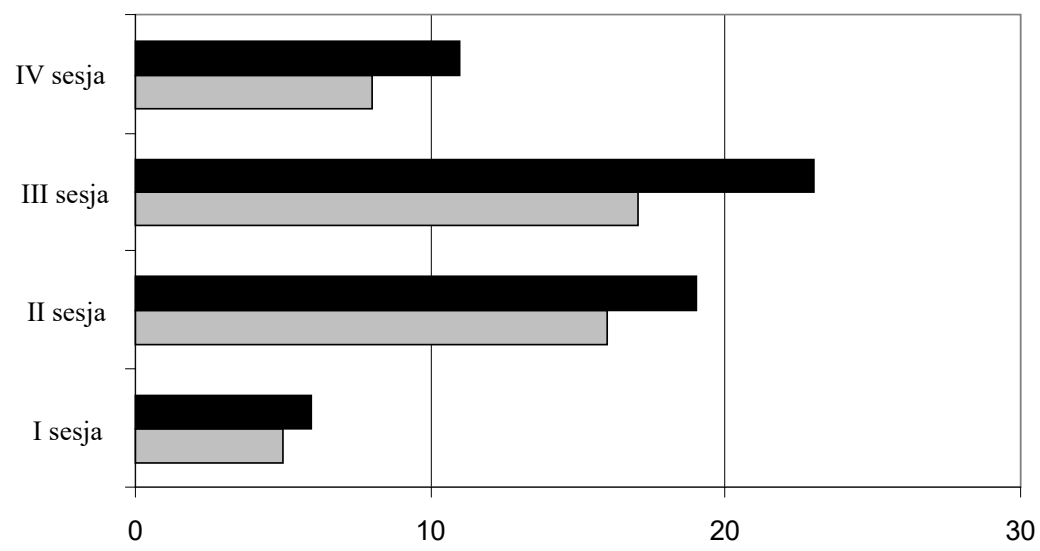

Biskupi ordynariusze

Biskupi sufragani i rezydujący w Rzymie

Wykres 10. Polscy ojcowie soborowi według ilości złożonych animadversiones podczas poszczególnych sesji Soboru Watykańskiego II

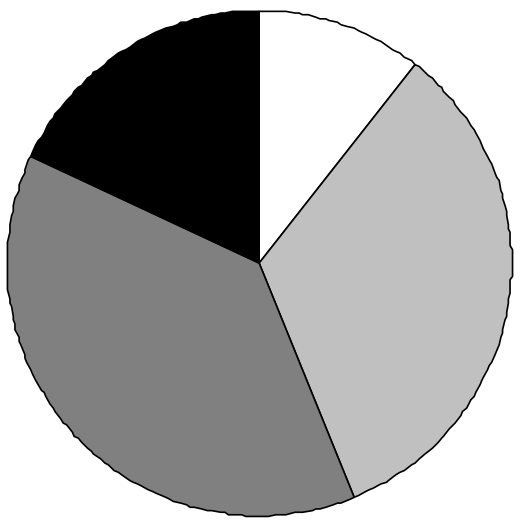




\section{Bibliografia}

\section{Źródla archiwalne}

\section{Archiwum Archidiecezjalne Warszawskie (AAW)}

AAW, SPP, Protokoły Komisji Głównej Episkopatu Polski, II 4/18.

AAW, SPP, Protokoły Komisji Głównej Episkopatu Polski, II 4/19.

AAW, SPP, Protokoły Konferencji Plenarnej Episkopatu Polski, II 4/200.

AAW, SPP, Protokoły Konferencji Plenarnej Episkopatu Polski, II 4/204.

AAW, SPP, Protokoły Konferencji Plenarnej Episkopatu Polski, II 4/211.

AAW, SPP, Protokoły Konferencji Plenarnej Episkopatu Polski, II 4/217.

AAW, SPP, Watykan, II 17/323.

\section{Archiwum Archidiecezjalne w Gnieźnie (AAG)}

Archiwum Archidiecezjalne w Gnieźnie, S. Wyszyński, Pro memoria, 1960.

\section{Źródła drukowane}

Białkowski M., Protokoty konferencji polskich ojców soborowych. Zbiór dokumentów 1962-1965, Lublin 2019.

Sobór oczami polskich komunistów. Sobór Watykański II w świetle dokumentów MSW i MSZ, wstęp, wybór i oprac. W. Kucharski, D. Misiejuk, Warszawa 2017.

Umiński J., Episkopat Polski z pierwszej połowy XX wieku, Toruń 2016, do druku przygotowali, wstępem i przypisami opatrzyli S. Grochowina, J. Sziling, Toruń 2016.

\section{Opracowania}

Augustyn Ciesielski. Dziedzictwo cystersów. Prace zebrane, red. M. Starzyński, M. Zdanek, Kraków 2013.

Bednarski D., Biskup Józef Gawlina jako opiekun Polaków na emigracji, Katowice 2019.

Bejze B., Kronika Soboru Watykańskiego II, Częstochowa 2000.

Białkowski M., Wokót Soboru Watykańskiego II. Studia i szkice, Toruń 2016.

Bielawny K., Udziat biskupów polskich w obradach Soboru Watykańskiego II, „Studia Ełckie” 2009, nr 11.

Borcz T., Biskup Bernard Czapliński w stużbie Kościoła chetmińskiego, „Studia Pelplińskie” 1980, nr 11.

Dembiński P., Poznańska kapituła katedralna schyłku wieków średnich. Studium prozopograficzne 1428-1500, Poznań 2012.

Dudek A., Gryz R., Komuniści i Kościót w Polsce (1945-1989), Kraków 2003.

Gmurczyk Z., Kościół włocławski w rzeczywistości PRL-u za czasów biskupa Antoniego Pawlowskiego (1951-1968), Włocławek 2015.

Grygiel L., Prorok ze św. Anny. Biskup Jan Pietraszko, Kraków 2017. 
Gryz R., Biskup kielecki Czesław Kaczmarek w starciu z komunistycznym totalitaryzmem, „Kieleckie Studia Teologiczne” 2005, nr 4.

Jujeczka S., Duchowni średniowiecznej Legnicy. Studium prozopograficzne nad klerem diecezjalnym, Legnica 2006.

Kasyna W., Bp Zygfryd Ignacy Kowalski (1910-1995), [w:] Ksiegga Jubileuszowa 350 lat Wyższego Seminarium Duchownego w Pelplinie (1651-2001), red. A. Nadolny, Pelplin 2001.

Kłoczowski J., Les évêques polonais et le Concile Vatican II, [w:] Le Douxième Concile du Vatican (1959-1965). Actes du Colloque organié par l'École Française de Rome collab. avec l'Université de Lille III, l'Istituto per a Scienze Religieuse de Bologne et de Dipartamento di Studio Storici del Medioevo e dell'eta contemporanea de l'Univ. di Roma La Sapienza (Rome, 28-30 mai 1986), Roma 1989.

Kopiczko A., Józef Drzazga, [w:] Poczet biskupów warmińskich, red. S. Achremczyk, Olsztyn 2008.

Krahel T., Biskup Aleksander Mościcki, „W Służbie Miłosierdzia” 1/2010.

Krajniak R., Duchowieństwo kapitut katedralnej w Chetmży do 1466 roku. Studium prozopograficzne, Torun 2013.

Ks. bp Władystaw Jędruszuk (1918-1994): pierwszy pasterz Diecezji Drohiczyńskiej. XX rocznica utworzenia Diecezji Drohiczyńskiej, red. M. Boguszewski, Z. Rostkowski, S. Ulaczyk, Drohiczyn-Łosice 2011.

Kucharski W., Komuniści i Watykan. Polityka komunistycznej Polski wobec Stolicy Apostolskiej 1945-1974, Warszawa 2019.

Łatka R., Episkopat Polski wobec stosunków państwo-Kościót i rzeczywistości społeczno-politycznej PRL 1970-1989, Warszawa 2019.

Nitecki P., Biskupi Kościoła w Polsce. Stownik biograficzny, Warszawa 1992.

Nowak T., Duchowieństwo ziemi wieluńskiej w drugiej połowie XV i początku XVI wieku. Studium prozopograficzne, Wielun 2016.

Nowicki T., Plebani archidiakonatu pomorskiego $w$ XVIII wieku. Studium prozopograficzne, Lublin 2008.

Prejs R., Administracja diecezjalna w Królestwie Polskim w latach 1864-1918. Studium prozopograficzne, Lublin 2012.

Prokop K. R., Biskupi Kościoła katolickiego w III Rzeczpospolitej. Leksykon biograficzny, Kraków 1998.

Prokop K. R., Pasterze i rządcy diecezji mińskiej, pińskiej i drohiczyńskiej, Drohiczyn 2006.

Przeniosło M., Stopnie, tytuly i stanowiska naukowe w II Rzeczypospolitej, „Res Historica. Czasopismo Instytutu Historii UMCS” 2012, t. 33.

Raina P., Arcybiskup Bronistaw Dąbrowski. Portret, Warszawa 2008.

Rola M., Wktad kard. Stefana Wyszyńskiego w prace Soboru Watykańskiego II, „Warszawskie Studia Teologiczne” III/1985-1990. 
Różański M., Duchowieństwo parafialne archidiakonatu uniejowskiego w XVIII wieku. Studium prozopograficzne, Łódź 2010.

Rutkowski P., Polscy biskupi jako ojcowie Soboru Watykańskiego II, Warszawa 2014.

Selejdak R., Tożsamość i działalność instytucji formacji kapłańskiej w Rzymie, „Collectanea Theologica” 79/1, 2009.

Skrzypczak R., Karol Wojtyła na Soborze Watykańskim II. Zbiór wystapień, Warszawa 2011.

Szczepaniak J., Duchowieństwo diecezji krakowskiej w XVIII wieku. Studium prozopograficzne, Kraków 2010.

Szetelnicki W., Lwowianin na drogach świata, Władysław Kardynat Rubin, Roma 1985.

Śledzianowski J., Ksiądz Czesław Kaczmarek. Biskup kielecki 1895-1963, Kielce 2008.

Walkusz J., Drugi Sobór Watykański - próba kontekstualnej interpretacji historycznej, „Colloquia Theologica Ottoniana” 2013, nr 1.

Warso A., Trudności paszportowe bpa Piotra Gotębiowskiego, „Kronika Diecezji Radomskiej” 2005, nr 14 (4).

Wereda D., Biskupi unickiej metropolii kijowskiej w XVIII wieku, SiedlceLublin 2013.

Wilk S. SDB, Episkopat Kościoła katolickiego w Polsce w latach 1918-1939, Warszawa 1992.

Wodzianowska I., Rzymskokatolicka Akademia Duchowna w Petersburgu, Lublin 2007.

Wojtyła K., Udział biskupów polskich w Soborze Watykańskim II, „Wiadomości Archidiecezjalne Warszawskie" 1971, nr 53 (5).

Wójcik W., Zagadnienia organizacyjne i proceduralne podczas I sesji Soboru Watykańskiego II, „Prawo Kanoniczne. Kwartalnik Prawno-Historyczny” 5/3-4, 1962.

Żaryn J., Biskupi polscy doby PRL jako przedstawiciele polskich elit, [w:] Biskupi w rzeczywistości politycznej Polski pod rzadami komunistów, red. R. Łatka, Warszawa 2019 [w przygotowaniu do druku].

Żaryn J., Dzieje Kościoła katolickiego w Polsce (1944-1989), Warszawa 2003. 
MICHAŁ BIAŁKOWSKI

\section{POLSCY OJCOWIE SOBORU WATYKAŃSKIEGO II. WSTEP DO BADAŃ NAD EPISKOPATEM KOŚCIOLA KATOLICKIEGO W PRL W LATACH SZEŚĆDZIESIĄTYCH XX WIEKU}

Streszczenie: Wśród polskich ojców soborowych - uczestników Soboru Watykańskiego II - wyodrębniono trzy kategorie związane ze sprawowanymi godnościami, urzędami oraz święceniami (biskupi ordynariusze; biskupi sufragani i rezydujący w Rzymie; wyżsi przełożeni zakonni). Analiza prozopograficzna całej zbiorowości przeprowadzona została w oparciu o cztery cechy służące opisowi: wykształcenia i formacji intelektualnej; doświadczenia pasterskiego - pokolenie sakry biskupiej (urzędu wyższego przełożonego zakonnego); udziału w obradach soborowych; aktywności w obradach soborowych. Badania pozwalają na sformułowanie następujących wniosków końcowych: 1) zdecydowana większość posiadała co najmniej stopień doktora, przy czym lepsze wykształcenie (stopien doktora habilitowanego oraz tytuły profesorskie), było udziałem przede wszystkim biskupów ordynariuszy; 2) ponad $25 \%$ polskich ojców soborowych studiowało na uczelniach rzymskich, a blisko $75 \%$ posiadało dyplomy uczelni polskich (najczęściej wybierano Katolicki Uniwersytet Lubelski); 3) wśród biskupów ordynariuszy dominowało pokolenie sakry (urzędu wyższego przełożonego zakonnego) 1946-1955, natomiast wśród biskupów i rezydujących w Rzymie pokolenie 1956-1965, a więc hierarchów młodych, często tylko z kilkuletnim doświadczeniem posługi biskupiej; 4) we wszystkich czterech sesjach Soboru Watykańskiego II uczestniczyło tylko 10 spośród wszystkich polskich biskupów; 5) w I sesji soborowej dominowali liczebnie biskupi ordynariusze, w trzech kolejnych biskupi sufragani i rezydujący w Rzymie; 6) najczęściej wystąpienia publiczne w auli soborowej wygłaszali biskupi ordynariusze - prawie $75 \%$ wszystkich przemówień polskich ojców soborowych, szczególną rolę spośród nich odegrali Prymas Polski kardynał Stefan Wyszyński oraz arcybiskup krakowski Karol Wojtyła; 7) odmiennie niż w przypadku wystąpień publicznych, większość animadversiones (pisemne uwagi), składali przede wszystkim biskupi sufragani i rezydujący w Rzymie (ponad 56\%); 8) polscy ojcowie soborowi stanowili największą delegację spośród episkopatów krajów Europy Środkowo-Wschodniej, często pełnili rolę przedstawicieli Kościoła milczenia zza „żelaznej kurtyny”, a ich udział w pracach Soboru Watykańskiego II miał znaczący wpływ na finalny kształt dokumentów soborowych.

Słowa kluczowe: Sobór Watykański II; polscy ojcowie soborowi; episkopat Kościoła katolickiego; Konferencja Episkopatu Polski; Kościół katolicki w PRL; analiza prozopograficzna; wykształcenie i formacja intelektualna; doświadczenie pasterskie - pokolenie sakry biskupiej (urzędu wyższego przełożonego zakonnego); udział w obradach soborowych; aktywność w obradach soborowych. 


\title{
POLISH FATHERS OF THE SECOND VATICAN COUNCIL. INTRODUCTION TO RESEARCH ON POLISH BISHOPS IN THE POLISH PEOPLE'S REPUBLIC IN THE SIXTIES OF THE $20^{\mathrm{TH}}$ CENTURY
}

\begin{abstract}
Summary: Three categories of Polish conciliar fathers - participants of the Second Vatican Council - have been set apart. These categories have to do with their dignities, offices and ordinations (ordinaries, suffragan bishops and residents in Rome, higher superiors in orders). Prosopographical analysis of these people was carried out on the basis of 4 factors: education, intellectual formation, pastoral experience, participation in conciliar debates. Following conclusions have been drawn: 1) Vast majority had a doctoral degree. Mostly ordinaries had habilitation and professorship. 2) Over $25 \%$ of Polish conciliar fathers studied at Roman universities and almost $75 \%$ had degrees from Polish universities. 3) Among the ordinaries the generation of the office of a higher order's superior - 1946-1955. Among bishops and residents in Rome dominated the 1956-1965 generation, i.e. the hierarchy of the young. 4) In all four sessions of the Council only 10 bishops took part. 5) In the first session ordinaries were a majority. In the following sessions suffragan bishops and residents in Rome were a majority. 6) Public speeches were held mostly by ordinaries $(75 \%$ of all speeches by Polish bishops). A special role was played by the president of Polish bishops' conference - cardinal Stefan Wyszyński and Cracow's archbishop Karol Wojtyła. 7) Different than in the case of public speeches, most animadversiones (written remarks) were submitted by suffragan bishops and residents in Rome (over 56\%). 8) Polish conciliar fathers were the most numerous delegation among bishops' conferences from Middle-Eastern Europe. They were representatives of the silent Church behind the Iron Curtain. Their participation in the works of the Council had a decisive impact on the final documents of the Council.
\end{abstract}

Keywords: Polish conciliar fathers, Catholic bishops, Polish bishops' conference, Catholich Church in PPR, prosopographical analysis, education and intellectual formation, participation in conciliar debates. 
